\title{
Ecological mitigation of hillslope instability: ten key issues facing researchers and practitioners
}

\author{
Alexia Stokes • Grant B. Douglas • Thierry Fourcaud • Filippo Giadrossich • \\ Clayton Gillies • Thomas Hubble • John H. Kim • Kenneth W. Loades • Zhun Mao • \\ Ian R. McIvor • Slobodan B. Mickovski • Stephen Mitchell • Normaniza Osman • \\ Chris Phillips • Jean Poesen • Dave Polster • Federico Preti • Pierre Raymond • \\ Freddy Rey • Massimiliano Schwarz • Lawrence R. Walker
}

Received: 19 April 2013 / Accepted: 22 January 2014 / Published online: 11 March 2014

(C) Springer International Publishing Switzerland 2014

\begin{abstract}
Background Plants alter their environment in a number of ways. With correct management, plant communities can positively impact soil degradation processes such as surface erosion and shallow landslides. However, there are major gaps in our understanding of physical and ecological processes on hillslopes, and the application of research to restoration and engineering projects.
\end{abstract}

Responsible Editor: Philippe Hinsinger.

A. Stokes $(\bowtie) \cdot$ J. H. Kim

INRA, UMR AMAP,

Bld de la Lironde, 34398 Montpellier cedex 5, France

e-mail: alexia.stokes@cirad.fr

G. B. Douglas

AgResearch,

Private Bag 11008, Palmerston North, New Zealand

T. Fourcaud

CIRAD, UMR AMAP,

Bld de la Lironde, 34398 Montpellier cedex 5, France

F. Giadrossich

University of Sassari,

Viale Italia 39, 07100, Sassari, Italy

C. Gillies

FPInnovations,

2601 East Mall, Vancouver, BC, Canada

T. Hubble

School of Geosciences, The University of Sydney,

Darlington 2006 New South Wales, Australia
Scope To identify the key issues of concern to researchers and practitioners involved in designing and implementing projects to mitigate hillslope instability, we organized a discussion during the Third International Conference on Soil Bio- and Eco-Engineering: The Use of Vegetation to Improve Slope Stability, Vancouver, Canada, July 2012. The facilitators asked delegates to answer three questions: (i) what do practitioners need

K. W. Loades

The James Hutton Institute,

Errol Road, Invergowrie, Scotland DD2 5DA, UK

Z. Mao · F. Rey

Irstea, UR EMGR,

2 Rue de la Papeterie, BP 76, 38402 Saint Martin d'Hères

Cedex, France

I. R. McIvor

Plant \& Food Research,

Private Bag 11600, Palmerston North, New Zealand

S. B. Mickovski

School of Engineering and Built Environment, Glasgow

Caledonian University,

70 Cowcaddens Rd, Glasgow G4 0BA Scotland, UK

S. Mitchell

Faculty of Forestry, University of British Columbia, 3041-2424 Main Mall, Vancouver, BC, Canada 
from science? (ii) what are some of the key knowledge gaps? (iii) what ideas do you have for future collaborative research projects between practitioners and researchers? From this discussion, ten key issues were identified, considered as the kernel of future studies concerning the impact of vegetation on slope stability and erosion processes. Each issue is described and a discussion at the end of this paper addresses how we can augment the use of ecological engineering techniques for mitigating slope instability.

Conclusions We show that through fundamental and applied research in related fields (e.g., soil formation and biogeochemistry, hydrology and microbial ecology), reliable data can be obtained for use by practitioners seeking adapted solutions for a given site. Through fieldwork, accessible databases, modelling and collaborative projects, awareness and acceptance of the use of plant material in slope restoration projects should increase significantly, particularly in the civil and geotechnical communities.

Keywords Erosion · Hydrology · Landslides · Dike (levee) $\cdot$ Soil bioengineering $\cdot$ Vegetation

\section{Introduction}

Plant roots alter their local environment in a number of ways, from modifying soil biophysical, chemical and mechanical properties, to stimulating microbial abundance and diversity. Through an understanding of these fundamental processes, adapted solutions can be devised for successful ecological restoration and soil protection. Plant roots can be used successfully to reinforce and 'fix' soil mechanically on hillslopes, riverbanks and

N. Osman

Institute of Biological Sciences, Faculty of Science,

University of Malaya,

50603 Kuala Lumpur, Malaysia

C. Phillips

Landcare Research,

PO Box 69040, Lincoln 7640, New Zealand

J. Poesen

Department of Earth and Environmental Sciences, KU Leuven,

Celestijnenlaan 200E, 3001 Heverlee, Belgium

D. Polster

Polster Environmental Services,

6015 Mary Street, Duncan, BC V9L 2G5, Canada artificial slopes, and are therefore an ecological alternative to civil engineering solutions when protecting against shallow landslides and soil erosion. On a global scale, landslides (excluding seismic induced landslides) resulted in approximately 4500 deaths annually between 2004 and 2010 (Petley 2012). India, China, the Philippines and Nepal suffer the most losses of human life, with landslides causing devastating consequences for communities and infrastructure.

Severe soil loss is a frequent problem where steep slopes and erodible soils are subjected to intense precipitation, particularly where vegetation has been compromised by deforestation, grazing, construction or agricultural use (Fig. 1a). Shallow landslides (Fig. 1b) and soil loss upslope can lead to high sediment yields that can cause downstream problems such as reservoir sedimentation and pollution. Riverbanks and dikes (levees) are particularly sensitive to substrate loss from scouring forces exerted by water fluxes (Fig. 1c). Artificial slopes in urban areas (e.g., road and railway embankments) and at mine sites can also be highly prone to failure resulting in infrastructure damage and major economic losses (Fig. 1d). In this paper we discuss the role that vegetation plays in stabilizing hillslopes and how we can improve our knowledge by using data from associated fields of research.

\section{Contribution of vegetation to the ecological mitigation of hillslope instability}

Surface erosion is defined as the detachment, transport and deposition of soil particles by an erosive process

\author{
F. Preti \\ Engineering for Agro-Forestry and Biosystems Division, \\ Università Firenze - GESAAF, \\ via san Bonaventura 13, 50145 Firenze, Italy \\ P. Raymond \\ Terra Erosion Control Ltd, \\ 2304 Silverking Road, Nelson, British Columbia V1L 1C9, \\ Canada \\ M. Schwarz \\ Bern University of Applied Sciences, \\ Länggasse 85, 3052 Zollikofen, Switzerland \\ L. R. Walker \\ School of Life Sciences, University of Nevada Las Vegas, \\ Box 454004, 4505 Maryland Parkway, Las Vegas, NV \\ 89154-4004, USA
}


Fig. 1 Substrate mass wasting processes are typically in the form of: a gully head retreat in rangeland by concentrated flow erosion at Guadix, Spain; b shallow landslides. Here, juvenile Salix matsudana Koidz. x Salix alba $\mathrm{L}$. trees planted at wide spacings to reduce soil slipping on pastoral slopes in Hawke's Bay, New Zealand; c river bank failure (e.g., soil fall after undercutting, near Jimma, South Ethiopia); and $\mathbf{d}$ failure of road embankment at Walker's Landing, British Columbia, Canada
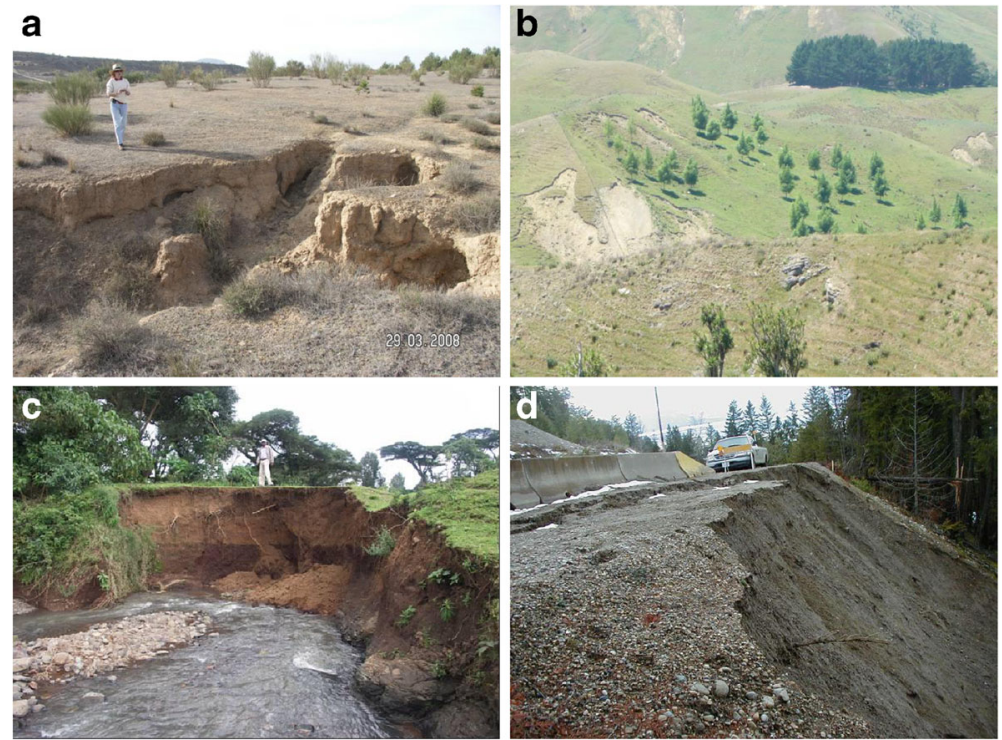

(e.g., water and wind; Gray and Sotir 1996; Boardman and Poesen 2006). Concentrated flow erosion (rill and gully erosion), resulting from erosion by water, causes the majority of soil loss (Fig. 1a, c). Problems typically occur at erosion hotspots where excessive soil loss takes place and large volumes of sediment are produced (Poesen et al. 2003). Across a landscape, these sites are often limited in extent, but may account for the majority of the catchment sediment yield.

Landslides are defined as processes that result in the downward and outward movement of slope-forming materials composed of natural rocks, soil, artificial fill, or combinations of these materials (Fig. 1b, Sidle and Ochiai 2006; Walker and Shiels 2013), with gravity and water as the primary triggers of landslides. To mechanically stabilize a slope against a shallow landslide, plant roots must cross the shear surface which may be up to $2.0 \mathrm{~m}$ below the soil surface (Norris et al. 2008). Thick roots act like soil nails on slopes, reinforcing soil in the same way that concrete is reinforced with steel rods. Thin and fine roots act in tension during failure on slopes, and if they cross the slip surface, reinforce soil by adding cohesion (Stokes et al. 2009).

To improve slope stability, the sustainable control of soil erosion and sediment production is necessary in the upslope portions of a given site or watershed. Vegetation contributes to water infiltration, soil surface protection, strength and fertility, as well as the enhancement of biological activity in the soil. Using vegetation in ecological rehabilitation or restoration projects will promote the recovery of ecosystem structures and functions, in addition to general ecological infrastructure. But vegetation also has the potential to destabilize slopes. For example, during high winds, tall trees can act as a lever, leading to their breakage or uprooting, with consequences for slope mechanical integrity (Mitchell 2013).

\section{Ecological engineering}

Installing vegetation on severely degraded slopes is difficult because of the strong erosive forces, especially in dry climates and on poor soils (e.g., with nutrient deficiencies, low organic matter content and low water holding capacity). The establishment of vegetation, nevertheless, is possible when combined with engineering structures or through the use of soil bioengineering or eco-engineering techniques. Soil bioengineering is defined as a technology that uses engineering practices in conjunction with integrated ecological principles to assess, design, construct and maintain living vegetation systems and to rapidly repair damage caused by erosion and failures (Norris et al. 2008; Stokes et al. 2010). Ecoengineering is described as the long-term, ecological and economic strategy to manage a site with regard to natural or man-made hazards (Stokes et al. 2010). Both fields lie within the discipline termed 'ecological 
engineering,' defined as the design of sustainable ecosystems that integrate human society with its natural environment for the benefit of both (Mitsch and Jørgensen 2004). Even though many successful case studies have been reported from regions with hilly and mountainous terrain, especially in the European Alps (e.g., EFIB 1999; Rey 2009), North America (e.g., Gray and Sotir 1996), Latin America (e.g., Petrone and Preti 2010) and south-east Asia (e.g., Barker et al. 2004; Sidle et al. 2006), improved knowledge is still required to increase the performance of mitigating actions whilst reducing the costs. Whereas civil engineering methods for protecting against erosion and shallow landslides focus on technical constructions and are often restricted to point-by-point or linear effects, ecologically engineered approaches are less developed, but can be more enduring, particularly when coupled with longterm socioeconomic shifts (Fig. 2, Böll et al. 2009). Practitioners and land managers need to understand the benefits and possible drawbacks of the use of vegetation in bio- and eco-engineering systems and to determine thresholds of effectiveness (Ji et al. 2012; Schwarz et al. 2012).

\section{Target readership for this paper}

The ecological mitigation of hillslope instability combines science and practice at the intersection of civil/ geotechnical engineering, geomorphology, soil science, hydrology, silviculture (if trees are used for timber), plant science, landscape design and ecological restoration. This paper is aimed at a broad range of people who have an interest in ecological engineering. Researchers interested in the use of vegetation to control soil erosion and shallow landslides will find in this paper some important knowledge gaps that need to be addressed. Working collaboratively, practitioners and researchers can design experimental systems for examining and modelling the component processes, test diagnostic approaches, design solutions and determine performance standards for those systems. Consequently, tools and guidelines could be developed to assist engineers when structurally incorporating vegetation into designs, thus combining ecological and conventional engineering.

\section{Identifying concerns of practitioners and researchers}

To identify the key issues of concern to researchers and practitioners, we organized a round table discussion during the Third International Conference on Soil Bioand Eco-Engineering: The Use of Vegetation to Improve Slope Stability, held at Vancouver, Canada, on 23-27 July 2012. Before the round table, we asked delegates (comprising researchers and practitioners) to write responses to the following questions:

1) What do practitioners need from science?

2) What are some of the key knowledge gaps?

3) What ideas do you have for future collaborative research projects between practitioners and researchers?

From this process, the following ten key issues were identified (Fig. 3).
Fig. 2 Technical (A) and socioeconomic (C) aspects of slope restoration are relatively well-documented compared to ecological aspects (B).

Nevertheless, all three approaches need improvement and better linkages (AB, BC, AC). Ecological approaches can be particularly helpful at larger and longer scales (e.g., landscapes and succession)

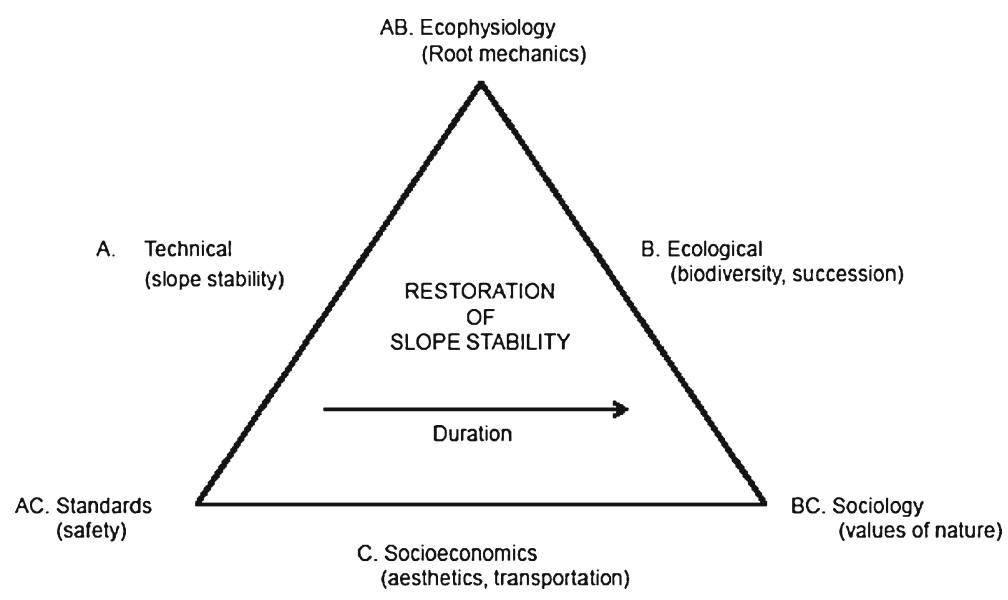




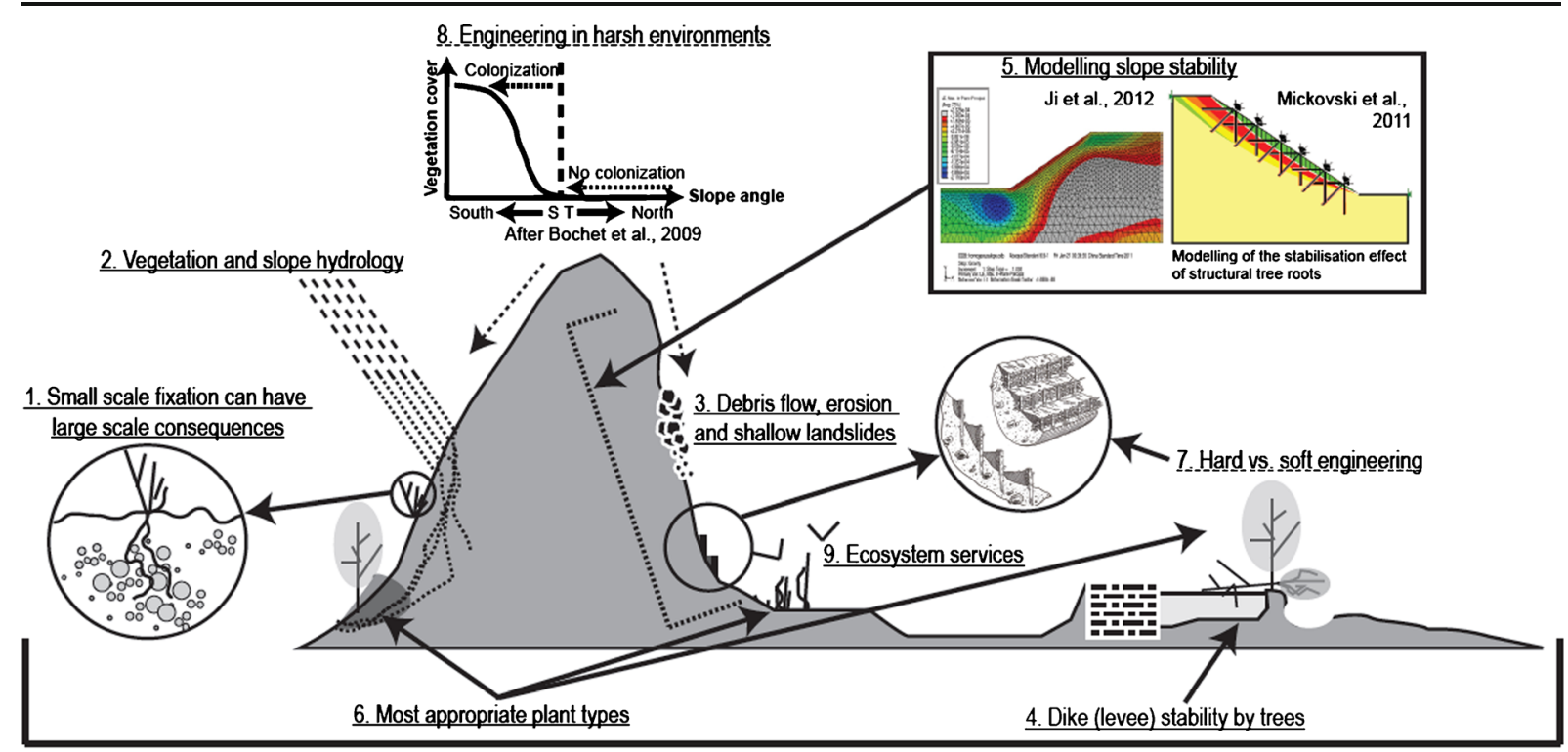

10. More widespread adoption driven by better understanding

Fig. 3 Schematic illustration of the ten key issues highlighted as of importance to researchers and practitioners investigating slope stabilization and erosion control

\section{Ten key issues for the mitigation of slope instability using ecological concepts and techniques}

1 Evaluating how small scale soil fixation can have large scale consequences

\section{Biophysical effects}

Slope instability and erosion control can be mitigated at different scales. Soil structure and aggregate stability (the percent of stable aggregates after a period of water immersion; Le Bissonnais 1996) can be enhanced rapidly by introducing vegetation (Jastrow et al. 1998; Gyssels et al. 2005; Fattet et al. 2011). Aggregate stability on slopes planted with Alnus incana (L.) Moench and Salix purpurea L. increased significantly after only 2 years, reaching values similar to naturally vegetated slopes (M. Schwarz, unpublished data). However, in certain soils, herbaceous vegetation is more efficient than trees in improving aggregate stability due to the greater density of fine roots and associated fungal hyphae, both of which enmesh soil particles (Gyssels et al. 2005; Fattet et al. 2011).

As plant roots grow within soils, root exudates are produced. These exudates lubricate the root tip when penetrating soils (Bais et al. 2006) and also stimulate microbial activity (Czarnes et al. 2000). Microbial communities increase the stability of aggregates through production of (i) extracellular polysaccharides and other compounds (e.g., glomalin, by bacteria and fungi which adhere mineral particles in soils; Wright et al. 2007) and (ii) hydrophobic substances (Capriel et al. 1990). Glomalin is a glycoprotein produced by arbuscular mycorrhiza and has been suggested to contribute significantly to the carbon stock in soils (Wright et al. 2007). The dynamics of carbon and polysaccharide production in soils will depend on several factors, including the distribution and turnover of fine roots, which are significantly associated with fungal hyphae (Jastrow et al. 1998). Fungal exudates also influence soil structure through secondary mechanisms, such as stabilization against mechanical stress due to increases in soil viscosity (Barré and Hallett 2009), as well as increasing stability through either changes in the hydrological properties of aggregates or through increasing the strength of bonds between particles (Czarnes et al. 2000; Peng et al. 2011).

\section{Chemical effects}

In certain soils, a positive relationship between aggregate stability and shear strength has been demonstrated (Frei et al. 2003; Fattet et al. 2011). Although the mechanism for this relationship is not entirely understood, it is hypothesized that shear strength within a soil matrix results from the resistance to movement at interparticle 
contacts, physical bonds formed across the contact areas and chemical bonds (Craig 2004). It is to some extent surface-dependent and any action that will hinder or promote the cohesive and frictional forces between adjacent particles will invariably affect shear strength (Ayininuola et al. 2009). Shear strength is therefore probably linked to some of the same bonding mechanisms as those involved in aggregation. Thus, the bonding mechanisms which strengthen aggregates internally may be similar to those which strengthen interaggregate structure (Bryan 2000). Vegetation can thus have a very local 'chemical' effect on soil shear strength, but requires further investigation to comprehend the underlying mechanisms involved.

To better quantify the direct and indirect roles of microbial communities on soil physical properties, inoculation and manipulative experiments could be performed to test if soil faunal/microbial composition mediates the effects of roots and land use on soil aggregate stability (Duchicela et al. 2012). However, techniques to improve aggregate stability in the field are far from being quantified and applicable in a way useful for practitioners. Therefore, the field is wide open for such novel studies over the next decade.

\section{Understanding the effects of vegetation on slope} hydrology

Soil hydrology is one of the main drivers of shallow landslides, and although precipitation events are often linked to the triggering of landslides, it is the change in pore water pressures that cause a slope to fail (Toll et al. 2011). As rainfall infiltrates soil on a slope, suction decreases, leading to a strength reduction and possible failure. In general, high water content (or low suction) is associated with weaker apparent soil cohesion and higher landslide risks; with low water content (or high suction) associated with stronger apparent cohesion and low landslide risk (Fredlund 1979).

Vegetation affects slope hydrology by intercepting rainfall, altering hydraulic conductivity through physical transformation of the soil by roots and transpiring stored water. Root water uptake (transpiration) and evaporation are two main removers of water from the soil layers, with both processes tightly coupled to canopy properties. Roots and other inputs of organic matter can also affect soil properties (e.g., porosity, water holding capacity and infiltration: Sidle and Ochiai 2006; Ghestem et al. 2011).

\section{Variations in soil moisture due to vegetation}

The interactions between vegetation type and its spatial and temporal effects on hydrological and mechanical effects on slope stability are still poorly understood. Vegetation is capable of removing large quantities of water from the soil, but how this translates to soil cohesion and whether this effect persists through season, soil types and depth is unknown for many vegetation types and climates. Some studies suggest that soil moisture in the root zone can still reach saturation periodically in more humid climates, eliminating additional cohesion from suction. From a study on the hydrological and hydraulic effects of riparian root networks on streambank stability in the southern USA, PollenBankhead and Simon (2010) concluded that the increase in soil matric suction from evapotranspiration provided the greatest potential benefit to bank stability, but only during the summer months. Similarly, during short and intense precipitation events (with 100 years return time) in alpine regions with small-scale, shallow, and rapidlyoccurring landslides, evapotranspiration was almost zero, interception rarely reached $5 \%$, and suction (and hence apparent cohesion) decreased rapidly in the potential shear plane (A. Askarinejad, pers. comm.).

How vegetation affects variations in soil moisture across depth is an important question for soil bio- and eco- engineers. For example, Briggs et al. (2013) showed that tree removal on railway embankments can increase pore water pressure at depths of $0.8-5.8 \mathrm{~m}$. Along natural slopes and elsewhere in a landscape, spatial variations in soil moisture, particularly levels of saturation, will vary greatly with topography. In clayrich soils, seasonal shrinking and swelling from fluctuations in soil water during the growing season may cause instability in artificial slopes, cuttings and embankments (Briggs et al. 2013). Unfortunately, establishing such hydrological effects of vegetation cover on a slope requires the deployment, monitoring and maintenance of soil moisture sensors and tensiometers for an appropriate number of seasons or years (Fredlund et al. 2012). On slopes undergoing restoration, management of hydrological processes is fundamental for the success of a soil bioengineering structure and vegetation establishment (Box 1). Assessment of terrain characteristics, such as runoff and drainage, is critical in determining the 
type, cause and position of a slope failure. Type of seepage, drainage patterns or surface precipitation can influence the choice of appropriate engineering techniques to drain saturated soil and re-establishment of vegetation (Box 1). However, data on the interaction between different vegetation types, engineering structures and slope hydrology over time are severely lacking, and remains an area where both fundamental and applied research studies are urgently required.

Box 1. Restoring slope stability in extreme conditions

Diverted drainage, due to increased stormwater runoff and heavy rainfall events above a public road in Southeast British Columbia, Canada, caused a landslide in February 2002 (Figure A). The increased velocity of this stormwater runoff created a deep vertical scar on the downstream end of the culvert crossing the road. To restore slope stability, the culvert was removed above the slope failure. The vertical scar (18 m wide $\times 70 \mathrm{~m}$ along the slope) was then filled with gravel, cobble, and small boulder material and was compacted from the bottom up using an excavator. In December 2002, a second failure occurred, depositing approximately $90 \mathrm{~m}^{3}$ of sand, coarse gravel and cobbles on the beach below. The slope gradients ranged from 35 to $45^{\circ}$. In March 2003, live pole drain systems i.e. cylindrical bundles made of live cuttings with rooting properties, used as a collector drain in conjunction with lateral drain fascines installed in a chevron pattern (Figure B, C), were installed to address underground seepage rising into the upper third of the slope. Vegetated lifts (brush layers placed between layers of soil, seeded and wrapped in natural geotextile), brush layers, fascines and live staking (planting of live poles) were installed at the same period. The component species of the structures were 80 \% Populus balsamifera ssp. trichocarpa Torr. \& A. Gray ex Hook., and $20 \%$ Salix scouleriana Barr. ex Hook. A soil amendment comprised of peat, organic fertilizer and mycorrhiza fungi was also used in conjunction with the installation of the structures. Grasses and legumes (e.g., Elymus trachycaulus (Link) Gould ex Shinners, Phleum pratense L., Medicago media L. and Trifolium hybridum L.) were broadcast seeded and native Alnus incana ssp .tenuifolia (L.) Moench, seedlings were planted to provide deep rooted nitrogen fixation to the soil. The site was then monitored until 2009 (Figure D) and the results showed a stable slope, very good survival of the structures, grasses and legumes and native herbaceous species such as Epilobium angustifolium L. and Rubus parviflorus Nutt. colonising the site. The average top growth on the brush layers was $3.5 \mathrm{~m}, 2.2 \mathrm{~m}$ for the live pole drains, $2.0 \mathrm{~m}$ for the live stakes, $3.3 \mathrm{~m}$ for the drain fascines and $1.5 \mathrm{~m}$ for the $A$. incana ssp.tenuifolia seedlings. It should be noted that the summer of $2007 \mathrm{was}$ the hottest on record with temperatures $>40^{\circ} \mathrm{C}$ and the site was not irrigated, yet plant survival was not compromised.

Figure A. Landslide at Walker's Landing Road, January 2003, British Columbia, Canada.

Figure B. Design of installed treatment providing surface drainage and deep rooting species/techniques such as brush layers and vegetated lifts. Figure C. Live pole drains and lateral drain fascines were installed to ensure drainage of materials along the slope, July 2003.

Figure D. View of site from bottom of slope, May 2009.

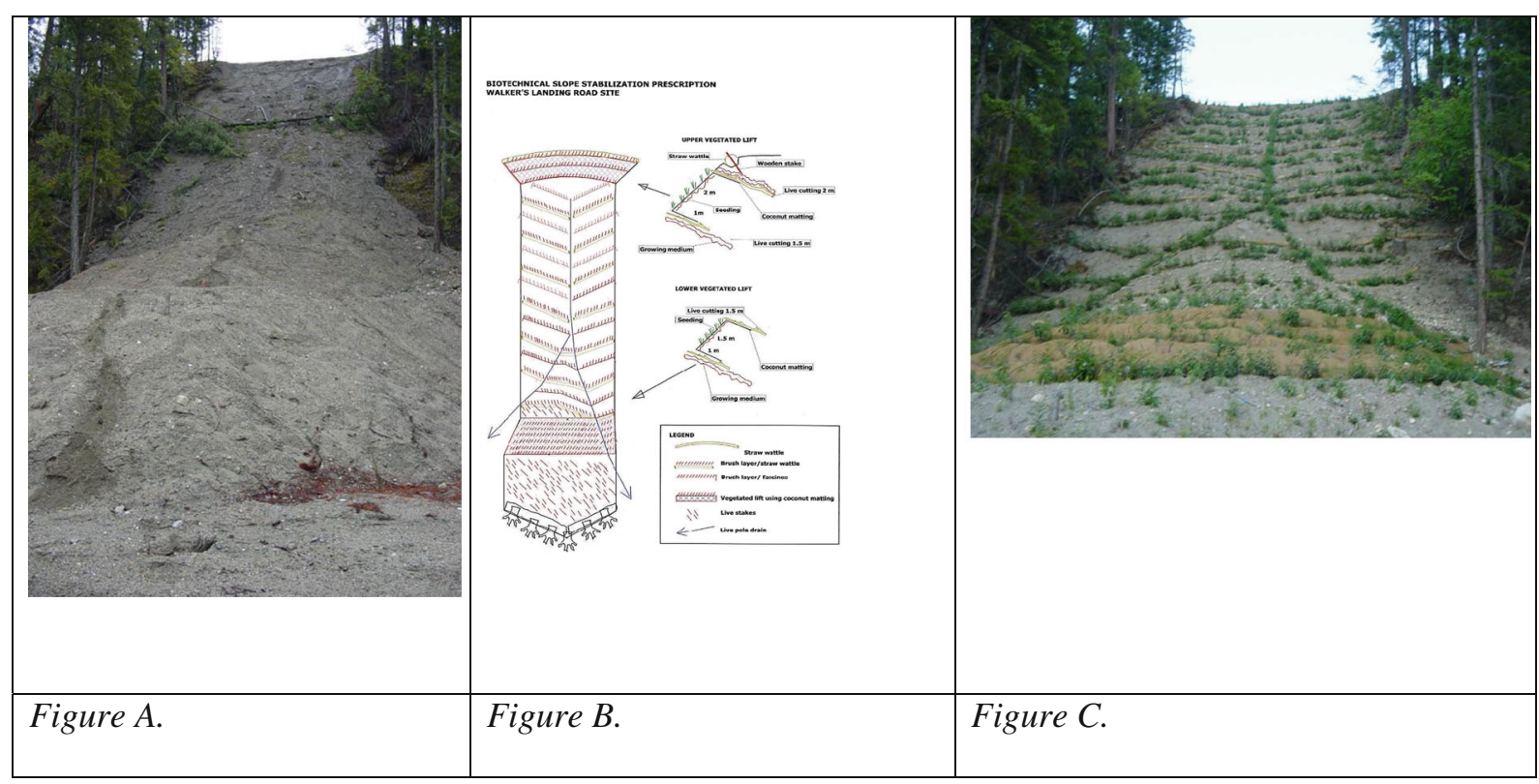




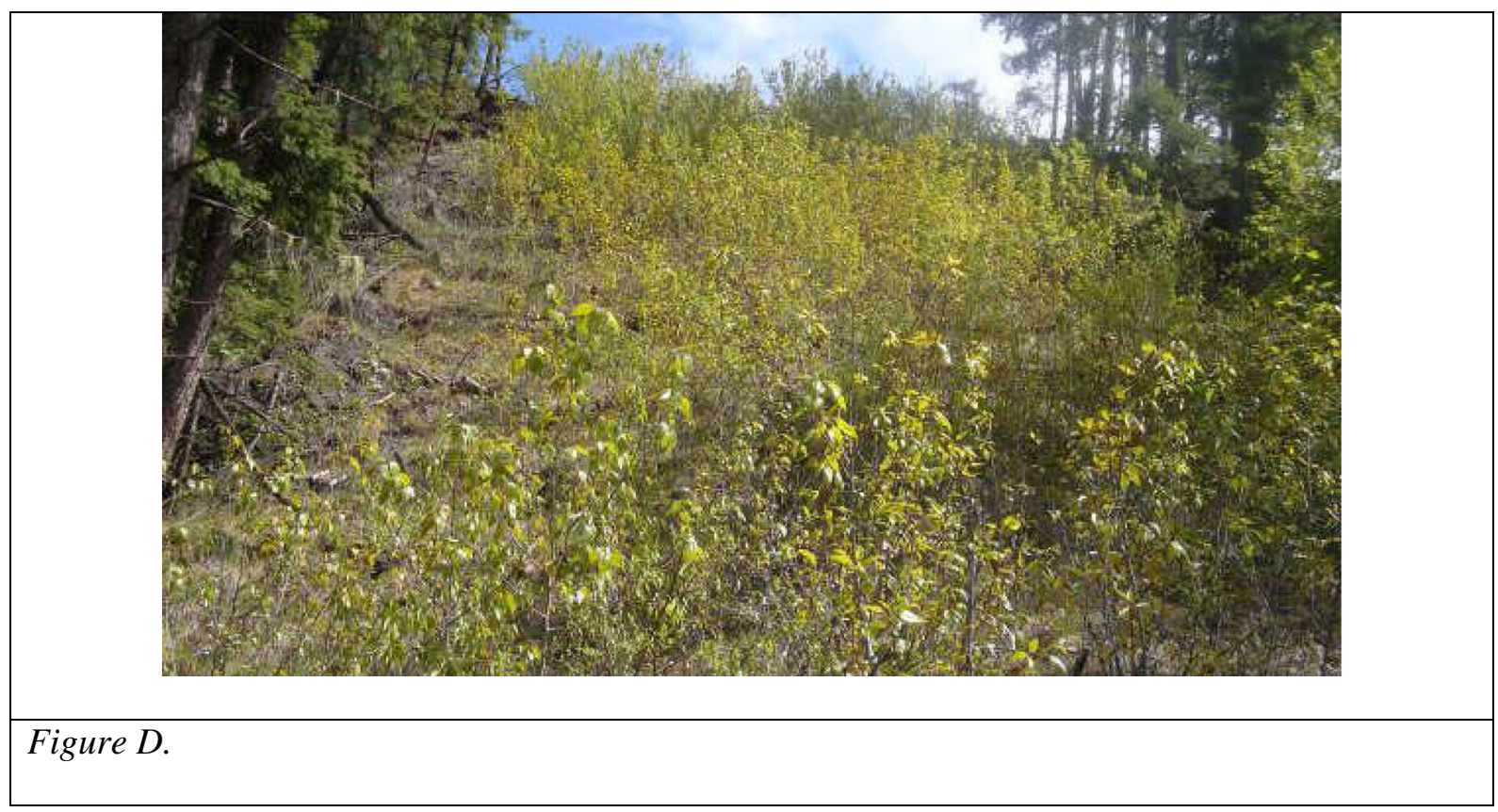

3 Understanding the role of vegetation in reducing debris flow activities

If left unchecked, soil erosion and slope failures can increase in width and length, and material can accumulate into zones that potentially mobilise as debris flows. Debris flows are mass wasting events characterized by a fast downslope movement of a mixture of fine materials (e.g., clay, silt or sand), and predominantly coarse materials including trees and logs (Jakob and Hungr 2005). The triggering of a debris flow is usually associated with high intensity rainfall events, sometimes with earthquakes, and is most frequent following vegetation removal, forest and brush fires and forest harvesting (Atkins et al. 2001). Once a channelized debris flow is triggered, the flow becomes highly erosive, mobilising materials and ceasing flow only when the gradient changes, usually on a fan, or if the flow depth decreases. Vegetation and soft engineering structures will probably be damaged or destroyed as velocities can reach $28 \mathrm{~ms}^{-1}$ (Pierson 1985; (Jakob and Hungr 2005). Debris flows can also occur as a shallow landslide transforms into a flow that stays on a slope and does not reach a channel. In such smaller scale events, velocities are much lower, with measurements indicating a range of mean flow velocities from 0.8 to $6.4 \mathrm{~ms}^{-1}$ (Rickenmann 1999). In these situations slope and flow depth determine how far debris will flow but vegetation may provide enough resistance to shorten the flow path.

\section{Avoiding recurrent debris flows}

Debris flows are extremely complex phenomena, and the use of vegetation in preventing or reducing flow will only be a partial solution. Vegetation can stabilize debris in channels before a flow event occurs (Jakob and Hungr 2005), but once a small scale debris flow has taken place, rapid engineering measures must be performed to prevent further failures occurring, especially if infrastructure exists downslope. After unstable debris has been removed or secured in place, controlling slope hydrology is the next fundamental step, and can be carried out using hard or soft engineering, such as with live pole drains (Boxes 1, 2). Small rock check dams can be established at regular intervals high in the gullies to prevent recurring events. These dams can be bolstered by installing living cuttings (e.g., willow cuttings) into the interstitial spaces between the rocks of the check dams. The roots and stems of the cuttings will help lock the rock in place, providing increased support for the check dams. Cuttings can be used to construct small check dams in a technique called "live gully breaks" and can also be installed in rows across the gully to form "live silt fences" (Polster 
2006). The cuttings will continue to grow as sediment accumulates, optimally creating strong attachments to the substrate. In addition to the direct effects of slowing potential debris flows, the root systems of plants used will help hold soils in place and prevent recurrent events.

Forest harvest practices can have a significant and longlasting geomorphic effect on the recurrence of debris flow events, because they determine the age of trees and type of felling procedure. For example, in the 1960s in Oregon, USA, clear-felling resulted in an increase in landslide frequency, but as many large logs were left in hollows and headwater streams, debris flow runout lengths were shortened. Therefore, more deposits were created upstream and became barriers to subsequent debris flows (Lancaster et al. 1999). If left unattended, old debris flows will be colonized by local vegetation and can help to stabilize the debris on the ground. Revegetation patterns will depend largely on the response of both vegetative resprouts and seedlings, the number of disturbances already incurred at the site, the initial species composition before the debris flow and the position of the regrowth along the debris flow (Gecy and Wilson 1990).

Many challenges exist in the avoidance of small scale debris flow processes and their recurrence using vegetation. We need a better understanding of how the spatial position of tree stumps and logs on a hillside after felling can increase or reduce debris flow activities. We also require precise empirical data on the stabilizing effects of soft engineering structures (with and without live vegetation) on debris in channels, thus preventing the triggering of a flow.

4 Understanding the impact of trees on the stability of dikes (levees)

\section{Loading effects}

Dikes are naturally occurring embankments or artificial fill slopes at the edge of watercourses that are similar in several ways to riverbanks or artificial slopes associated to infrastructure. Nevertheless, the problems associated with vegetation and dike stability are specific to dikes, because of the hydrological loading to which they are subjected. Dikes offer favourable conditions for tree growth with vegetation providing many ecological and social services. Trees and woody vegetation may improve dike stability, but can also induce risks which compromise their stability (e.g., increased infiltration and seepage associated with live or dead roots, an increase in the number of burrowing animals, and the potential for rootsystem pullout during floods or wind storms (Zanetti 2010; Corcoran et al. 2011). Corcoran et al. (2011) summarized the results of an integrated set of investigations on dikes in the US, and found that trees can increase or decrease the factor of safety (FOS) with respect to dike stability. The FOS is an indicator to evaluate the stability of a slope or bank, and is described as the ratio between the resisting forces and the driving forces on a slope (see Norris et al. 2008). Depending on the location of a tree on a dike, in terms of tree uprooting, the FOS decreases as wind speeds exceed $60 \mathrm{~km} / \mathrm{h}$. Tree weight, location, root system type, and wind loads are thus all significant parameters that must be taken into account when evaluating the effect of a tree on dike erosion for a particular site.

\section{Internal erosion}

To characterize the effect of woody root systems on the structure and durability of embankment dikes, Zanetti (2010) examined the growth and architecture of more than 100 root systems of common tree species in France. Tree root structure depended on the species, age and type of materials constituting the dike and on the position of the tree on the dike. Results showed that the architecture of tree root systems and root decomposition significantly influenced the rate of subsurface erosion, or piping, in a dike. Piping occurs when erosion processes result in formation of pipes that lead to a sagging of the dike core with subsequent overtopping, slope failure and collapse (Vrijling 2001). Root systems composed of long and thick roots, especially vertical taproots, could significantly increase piping, thus decreasing the mechanical integrity of a dike. Fast-growing, hydrophilic, juvenile species (e.g., Acer negundo L., and Populus sp.) can have roots grow up to $5 \mathrm{~m}$ in length, and should also be avoided on dikes. The roots of certain species such as Robinia pseudoacacia L. decompose very rapidly in soil, increasing the risk of piping, compared to species such as Fraxinus sp.. Future research should focus on the impact of root decomposition on internal erosion, and whether it is safe to leave tree stumps and their root systems in place, or if they should be removed. Until advances are made in this area, it is difficult to fully assess the impact of woody vegetation on the progression of piping. Zanetti (2010) argued that woody vegetation is negative for stability on narrow dikes, but is tolerable, with correct management, on parts of wider dikes. However, on newly constructed dikes, Zanetti (2010) suggests that grass mats are the best solution as ground cover. 
More studies are urgently needed to determine the best vegetation types or combinations of vegetation with substrate on dikes, depending on dike age, geometry and loading constraints. With regard to trees in particular, information on root system architecture, root growth rates and wood durability would provide practitioners with data which would enable them to more efficiently manage trees on dikes.

5 Modelling the mechanical stability of vegetated slopes

\section{Modelling in different dimensions}

Although several commercial and freely available tools for calculating slope stability exist, they are often not able to accurately predict the likelihood of a landslide within a given landscape. Many tools are based on oversimplified models that do not satisfactorily represent the main underlying mechanical and hydrological processes involved in the reinforcement of slope stability by vegetation. For example, most models cannot describe the three dimensional (3D) spatial heterogeneity of vegetation. Nor can these models describe realistic slope geometry as they are two dimensional (2D). As vegetation can result in lateral effects on a slope, such as arching effects (i.e., a difference in stiffness between the vegetation and the surrounding soil; Fan and Lai 2014), such beneficial effects will not be estimated in 2D models. One of the biggest challenges in model development is to appropriately take into account the temporal and spatial heterogeneity of soil properties, root and water distribution along a slope. The use of root demography and water flux data in 3D and four dimensions (4D, i.e., considering temporal variation) as model inputs is still largely unexplored (Mao et al. 2013). New technologies for including the 3D spatial distribution of root and soil properties in models with appropriate computation times are urgently required. The development of root growth models that provide spatial patterns of root distribution or density over time (Bonneu et al. 2012), also remains a priority. Such approaches should be able to account for the different physical contributions of plant root system architectures to slope stability and should also be based on reliable physical modeling of water flow in the soil. For example, the SOSlope model (Schwarz and Thormann 2012; Schwarz et al. 2013) implements the 3D spatial heterogeneity of root reinforcement in terms of forcedisplacement under tension and compression. Results enable maps to be created at the hillslope scale for the localization of single shallow landslides, as well as defining the volume of soil mobilized for a given rainfall event. Because soil depth and strength are implemented as random variables at the hillslope scale, Monte Carlo simulations can be run to obtain maps showing the probability of failure. In the 3D slope stability model Ecosfix 1.0, a variety of forest management scenarios can be implemented, to allow the user to determine the effect of tree felling and regrowth on slope stability, over time and space (Mao et al. 2014). The possibility to localize and define the volume of shallow landslides also represents a major advantage for a realistic simulation of dynamic processes such as debris flows and sediment transport at the catchment scale.

\section{Alternative models}

One of the most common outputs of numerical simulations of slope failure is the FOS. Most prevailing models consider FOS as a global "slope scale" indicator and thus compute only one FOS value to represent the average stability of a whole slope. While this approach may be appropriate for relatively small slopes under full cover of homogenous types of vegetation (e.g. Mickovski and van Beek 2009), the use of a global FOS will probably mask details of small-scale effects of vegetation on slope stability. In the future, modellers should define alternative safety indicators to give more accurate details of slope stability as a function of time and space. Developing alternative techniques adapted to specific situations is an urgent priority. One of the most common approaches consists of using the Finite Element Method (FEM) to solve mechanical and/or hydrological continuous equations (Mickovski et al. 2011; Ji et al. 2012; Mao et al. 2014). Although classical FEM is well adapted to cohesive soils, this method can be inadequate for granular substrates. Therefore, alternative techniques such as the Particle finite Element Method (PEM, Onate et al. 2004) or the Discrete Element Method (DEM, Radjai and Dubois 2011) are useful. DEM was used recently by Bourrier et al. (2013) to simulate the mechanical interactions between roots and soil in a shear test at a small spatial scale. Coupled hydromechanical equations, which are represented with partial differential equations, can be directly solved using FEM. But DEM, which is based on the calculation of mechanical interactions between soil grains including capillary forces, must be associated with models of continuous fluid dynamics to take into account ground water movements (Donzé et al. 2009). Future models and modeling approaches need to be robust (able to represent and deal with a large variety of situations), transparent, and based 
on clearly defined assumptions in order to ensure greater uptake from the practitioners.

In order to provide useful 3D integrated models of slope stability, the greatest challenges for modellers will be to: (i) provide anisotropic and time dependent constitutive models of soil reinforcement by integrating knowledge at single root and root system scales; (ii) develop root growth models that will provide input information to soil reinforcement models; (iii) formalize mathematically the mechanical and hydrological processes involved in slope stability analysis over space and time; (iv) implement numerical solvers within dedicated software to integrate models at the slope scale.

6 Identifying the most appropriate plant types

\section{Limitations in the use of traditional species}

Several plant genera have often been preferred by soil bioengineers carrying out slope restoration in different parts of the world. These species have various properties permitting the rapid stabilization of an unstable or failed slope. The most popular tree/shrub species are the pioneers poplar (Populus sp.) and willow (Salix sp., Box 2) because they propagate readily from vegetative cuttings, or 'live poles,' if placed immediately in contact with moist soil (Wilkinson 1999; McIvor et al. 2014). Willow species, in particular, are also used for a range of functions in riparian areas, including streambank protection and nutrient and sediment management (Kuzovkina and Volk 2009). Unlike seedlings or saplings, which possess root systems that develop close to the soil surface, cuttings (i.e., before the root system has developed) can be buried to a depth of up to $2.0 \mathrm{~m}$ in the soil. The slope then becomes reinforced with these poles (Rey 2009). On hillslopes and riverbanks, both poplar and willow poles quickly develop extensive lateral root systems that can interlock sufficiently with neighbouring trees (McIvor et al. 2009; Douglas et al. 2010).

Box 2. Engineering slope stability on a large scale using soft engineering structures

\begin{abstract}
In the French Southern Alps, where the Mediterranean climate is characterised by hot summers and heavy rainfall events, high sediment yields at the exit of marly catchments (Figure A), cause significant socio-economic and ecological problems downstream. In 2002, brush layers with or without brush mats on wooden sills (Figure B) were installed in gullies to: i) enhance vegetation development, ii) allow efficient and sustainable sediment trapping and iii) decrease sediment yield at the gully and catchment exits (Rey 2009). Plant material used in brush layers was willow (Salix purpurea and S. incana) cuttings. Today, more than 2000 brush layers have been installed in 160 marly gullies and about one third of these structures are surveyed. Results showed that these bioengineering structures can resist high hydrological forces, even when exposed to intense precipitation events with a return period of almost 100 years. Natural succession of native plants was also initiated on and around brush layers. Significant quantities of sediment were trapped from the first year onwards (Rey and Burylo 2014) and continuously (Erktan and Rey 2013). Sediment yield will therefore be substantially decreased at the gully and catchment exits. This case study provides design criteria to guide future restoration actions in both the French Southern Alps and similar regions worldwide.
\end{abstract}

Figure A. Water erosion in marly gullies in the French Southern Alps.

Figure B. Brush layers with brush mats on wooden sills.
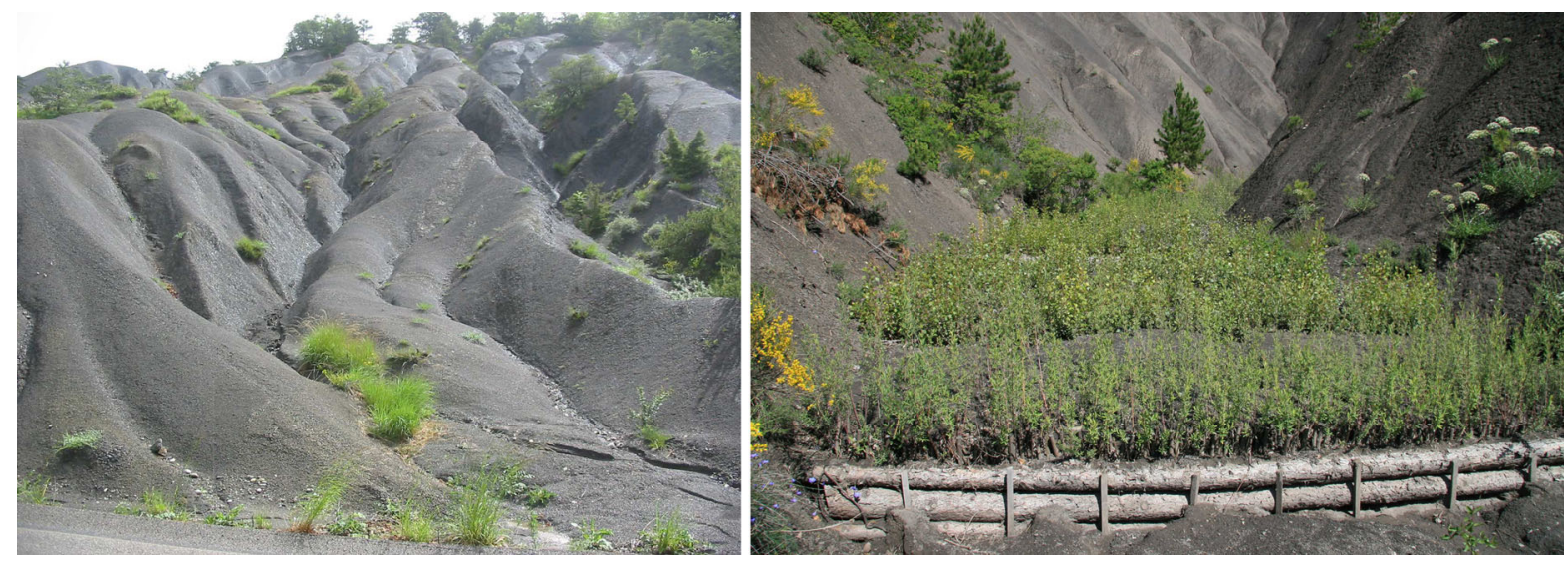
Mixtures of herbaceous species have been used mainly to provide protective ground cover on erodible slopes and reduce surface erosion processes (Zuazo and Pleguezuelo 2008). In tropical and subtropical climates there has been widespread use and promotion of vetiver grass (Chrysopogon zizanioides (L.) Roberty (syn. Vetiveria zizanioides (L) Nash)) for stablising slopes (National Research Council 1993). The most impressive characteristic of vetiver grass is that its root system consists of fibrous roots reaching depths up to $3.0 \mathrm{~m}$ (Hellin and Haigh 2002). Trials on vetiver grass in a semi-arid region of Spain (Mickovski et al. 2005, Mickovski and van Beek 2009), showed that soil depth and density, water availability and, to a lesser extent, air temperature, influenced root development. Even with small root systems, vetiver grass was able to withstand relatively high uprooting forces and trap sediments.

Vetiver grass, poplar and willow species may be used as pioneering or intermediate species in a vegetation succession, or be used as the final vegetation form to stabilize slopes, enabling various landuses to be practised such as grazing and cropping for food or energy. Although these species have proven highly adequate for reinforcing soil on slopes, there are a number of risks associated with reliance on a single species for rapid slope stabilisation and on early successional species for sustained slope protection. These risks include the potential for widespread destruction or reduced 'performance' because of pest and disease incursions and a limited ability to adapt to environmental changes. Monospecific planting may result in a species becoming invasive, especially if exotic to the region where planted. Similarly, such species may arrest succession processes and reduce colonization by native species, through e.g., forming dense thickets, capturing available resources and escaping predators from the home range (Walker et al. 2010). In addition, the risk of using only early successional species, even in their native environments, is that they may be short-lived.

Knowledge about supplying planting material and establishing and managing a single species in one location may not be readily transferable to other locations or species. Therefore, alternatives to the "quick fix" with a single species should be preferred where the risk of immediate slope failure is low. The choice of alternative species requires knowledge of appropriate plant traits, and should involve the screening of different species (Preti and Giadrossich 2009; Normaniza and Barakbah 2011).
Criteria and challenges in the selection of alternative species

To screen for the most appropriate plant, or mixture of plants, biophysical and ecological assessments are required (e.g., of growth rate, establishment costs, survival rate, colonisation requirements, life form, longevity and successional dynamics). These characteristics are particularly important to consider when choosing whether to install trees, shrubs or herbaceous species. Grasses and ground cover species can reduce superficial erosion and the propagation of soil cracks, thus avoiding the creation of preferential flow pathways along fissures leading to subsequent mass failure. Deeper-rooted woody perennials will improve the mechanical reinforcement of soil at depth. Ecologically appropriate plant materials are those that exhibit ecological fitness for their intended site, display compatibility with other members of the plant community, mediate succession and demonstrate no invasive tendencies (Jones 2013). Guidelines can then be devised for the choice of suitable plant species based on such ecological and biogeographical features (Evette et al. 2012). However, screening for social acceptance and ease of use/availability is also a priority (Fig. 2). Reubens et al. (2011) proposed such a system to select the most suitable endemic tree species for rehabilitating degraded land in northern Ethiopia. These authors examined socio-economic functions as well as socio-cultural values and environmental services.

Screening of plant species should start with a selection of key criteria that must be met by a particular species to effectively control a targeted slope instability or erosive process (Fig. 4). Once it has been determined if a plant is suited to a given environment (i.e., temperature, light, nutrient and water requirements are ascertained), above- and below-ground plant traits should be taken into account. Traits to consider include stem density, the potential to trap sediment and organic debris, stem bending stiffness, root density, root area ratio (RAR, i.e., the fraction of a plane of soil occupied by roots), root system morphology and root tensile strength (De Baets et al. 2009; Stokes et al. 2009; Giadrossich et al. 2012; Bischetti et al. 2014, this issue; Ghestem et al. 2014 this issue). A scoring system for potentially useful species would indicate the most and least suitable plants in a given landscape and needs further development (Fig. 4, De Baets et al. 2009). 


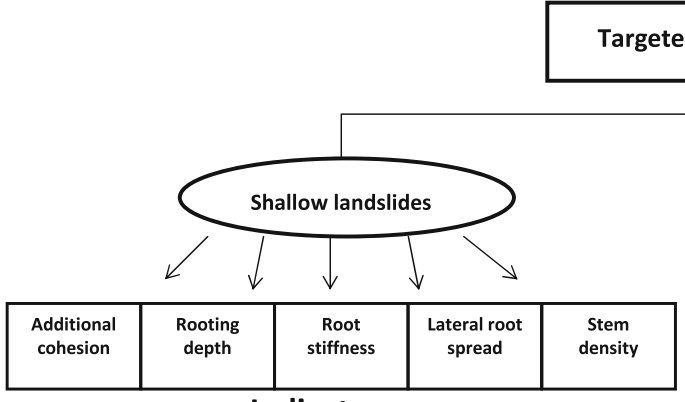

Indicators

Fig. 4 Screening of native plant species should start with a selection of key physical criteria that must be met by a particular species in order to effectively control a targeted substrate mass wasting process. Indicators need to be identified which allow for

\section{Dynamic evolution of vegetation}

Although individual species can be used to provide a significant contribution to mitigating hillslope instability and rendering land use sustainable, to restore full ecosystem function, replacement of pioneer plants by later successional communities is highly desirable. Pioneer shrub and tree species are often short-lived and unable to reproduce in their own shade and may only enhance stability for a limited period. Nevertheless, in later succession, large trees may uproot during high wind events (Mitchell 2013). Therefore, if trees grow too tall for a fragile slope, they may need pruning or felling to ensure that the integrity of the slope (or engineering structure) is not compromised through tree fall. During the time it takes for succession to occur, the degraded area of a slope may increase in size, thus rendering the slope more difficult and costly to manage. Thus, engineering structures, or techniques, may be necessary to prevent the spread of degradation. However, the establishment of vegetation and succession processes can reduce the necessity for intervention and be a long-term (decadal and more) solution for restoration (Walker and Shiels 2013), therefore providing the best compromise between artificial and natural slope stabilization. If the vegetation cover can naturally increase on slopes stabilized using e.g. soft bioengineering techniques, it should augment the protection acquired over time. The dynamics involved in these processes and the inhibiting factors warrant investigation. It is necessary to evaluate i) the ability of neighbouring (i.e., not planted by the practitioner) vegetation to colonize a target site via seed dissemination or by the practitioner creating a local seed bank; ii) if soil conditions, especially water

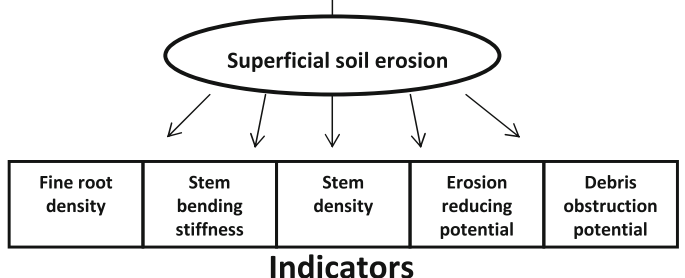

rapid assessment of the most suitable plants. We propose the following indicators as the most useful to measure when studying shallow landslides and superficial soil erosion

availability, will affect adversely germination, seedling survival and subsequent plant growth (Rey et al. 2005). Therefore, the researchers' challenge is to determine how the trajectory of ecological change can be influenced by site conditions, by the interactions of the species present, and by more stochastic factors such as availability of colonists or seeds, or weather conditions at the site. If such dynamics are not conceivable, longterm man-made actions should be envisaged as soon as possible.

7 Using inert engineering structures and live plant material and their efficacy over time

\section{Hard and soft engineering structures}

Hard engineering structures such as gabions, retention walls, anchors and check dams, provide an immediate solution for slope and (gully) channel stability. Soft engineering structures, such as brush layers or fascines, can be constructed with wood or live plant cuttings (Gray and Sotir 1996, Boxes 1, 2), but take longer to fully stabilize soils. These soft structures are suitable where a slope instability problem is anticipated and the live plant material is likely to have time to develop sufficient strength, perhaps within a period of several years. This delay in attaining adequate strength by the vegetation is an inherent weakness of soft engineering structures. Similarly, intra-annual variations in root demography (Mao et al. 2013) and soil moisture (Pollen 2007), result in periods of the year when slope stability is reduced and these inter- and intra-annual windows of susceptibility should be better defined and quantified. 


\section{Monitoring longevity and efficacy over time}

The lifetime of a hard engineering structure used to stabilize a slope or conserve soil is usually $50-100$ years with regard to optimal quality, but this timeframe is highly variable for soft engineering structures using non-living plant material (e.g., crib-walls and slope grids, Böll et al. 2009). Longevity of inert soft engineering structures depends on the species used and the biological activity of local degrading organisms (Lacasse and Vanier 1999). Therefore, any data on longevity of structures is only valid for similar conditions. The durability of wooden structural elements is dependent on air temperature, humidity and soil moisture variability (Lacasse and Vanier 1999). Wood decay in soft engineering structures can be estimated through monitoring physical properties such as wood density (Rinn et al. 1996). Monitoring external structural elements in crib-walls in Tuscany, Italy, Guastini and Preti (unpublished data) showed that decay was less than $10 \%$ after 10 years (Fig. 5).
Monitoring programs help to establish the lifetime and efficacy of vegetation and engineering structures on slope stability and erosion control in different pedoclimatic environments, for example, in Hong Kong, monitored data from soil bioengineered sites are catalogued in geo-referenced databases (http://hkss. cedd.gov.hk). With regard to large-scale slope stability, the effectiveness of vegetation over time can be tracked using remote sensing coupled with ground truth measurements (Forzieri et al. 2009; Schwarz and Thormann 2012). This method is particularly effective when assessing the damage on hillslopes following major storm events or silvicultural measures, and can provide information on e.g., the increase in rainfall-triggered landslides due to root decomposition after tree felling (Preti 2013). Developing and maintaining monitoring programs and databases is a major challenge, but information obtained would help engineers design the correct structure for a given problem, depending on the immediate requirements and long-term specifications for the site.

\section{a Evolution of living parts in bank cribwalls (Casentino, Tuscany, Italy)}

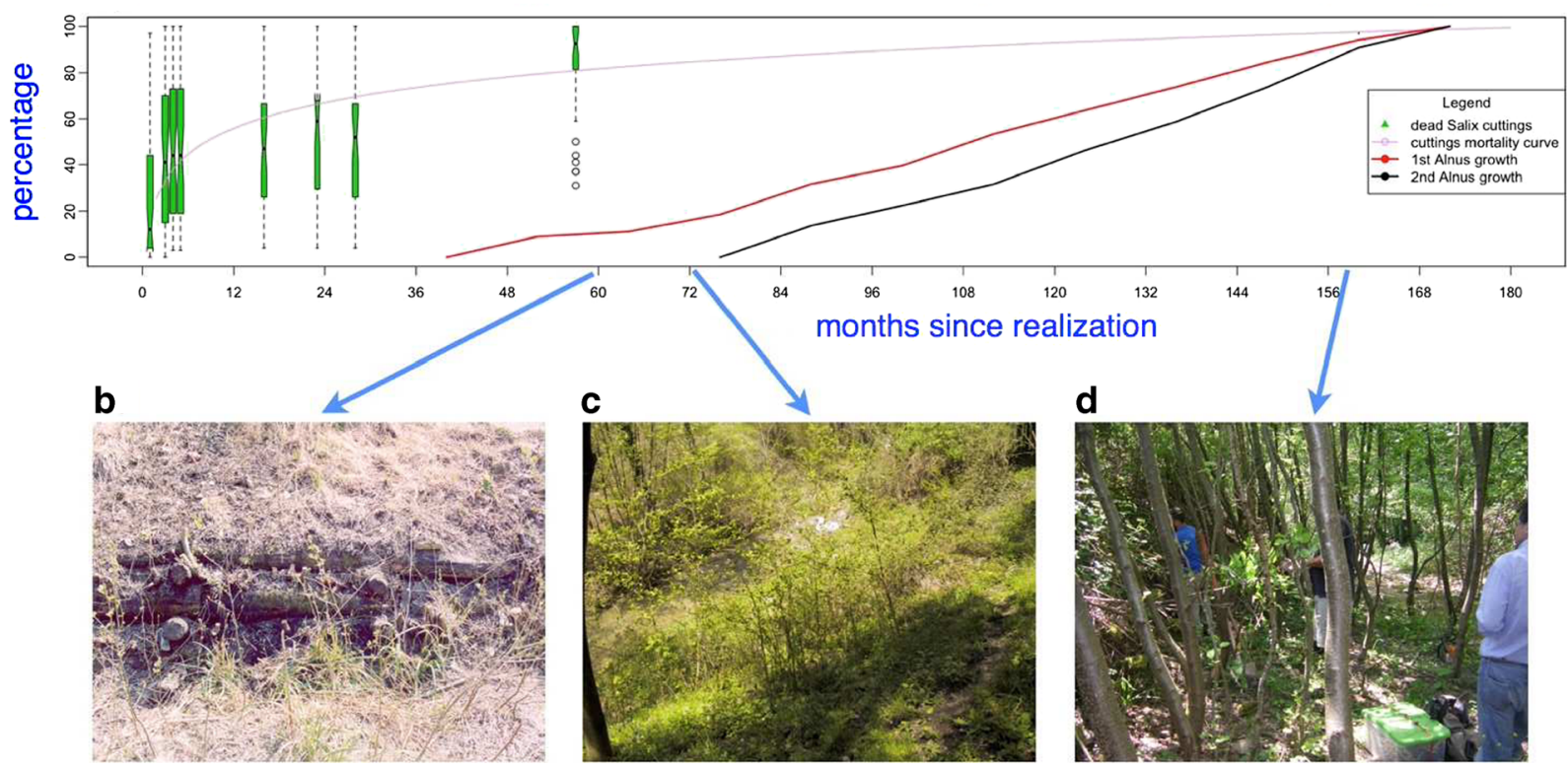

Fig. 5 Cribwalls constructed with live Castanea sativa Mill. poles were installed along the Sova River, Italy, in 1998. Salix alba L. cuttings (about $1 \mathrm{~m}$ long) were planted into the structure and native Alnus glutinosa L., regenerated naturally between the cribwall and the river. a Mortality (\%) of $S$. alba cuttings was measured over time, (dead cuttings/total cuttings), along with the height of A. glutinosa (growth curves from two studied representative trees. A growth curve is height reached at time $i$ /final height). After
57 months, $S$. alba was pruned through shoot removal, and the vigorously growing $A$. glutinosa shaded the subsequent $S$. alba rejects, resulting in their poor growth. b $S$. alba cuttings were pruned and several $A$. glutinosa seedlings can be seen in front of the cribwall (photograph taken in March 2003). c A. glutinosa grew faster than S. alba sprouts (April 2004). d In May 2011, A. glutinosa dominated significantly, shadowing almost completely the three remaining $S$. alba cuttings (Guastini and Preti, unpublished data) 


\section{The consequences of vegetation removal over time}

Where only vegetation (without site preparation or engineering structures) is used on large-scale slopes (e.g., forest plantations or ecosystems), soil reinforcement by root systems will depend largely on tree species, dimensions and vegetation management activities such as planting and thinning (Genet et al. 2008; Preti et al. 2010; Schwarz et al. 2012). In plantation forests of Cryptomeria japonica D. Don., in Sichuan, China, the maximum mechanical contribution of roots (or additional cohesion) to slope stability occurred in stands with 9 year old trees, and decreased with plantation age, due to tree removal through thinning (Genet et al. 2008). However, in a nearby mixed forest undergoing natural succession, additional cohesion increased significantly with tree age because soil was increasingly occupied by tree roots (Genet et al. 2010). After forest thinning or clear-felling, root systems left in the ground will decompose over time, reducing root mechanical strength and RAR. These sites are more susceptible to failure, until new vegetation colonizes the soil (Watson et al. 1999; Ammann et al. 2009; Preti 2013). Root wood durability (i.e. resistance to decomposition) will differ significantly between: (i) species, (ii) roots of different ages and (iii) along a single root (linked to the age of each root section: root sections containing heartwood will be more durable) (Zanetti 2010). More data are urgently needed on root decomposition rates and their influence on soil structure via microbial processes and slope hydrology through changes in infiltration rates (Ghestem et al. 2011). A better understanding of all the effects of vegetation removal on a site would allow for more precise modeling of vegetated slope stability over time and space (Mao et al. 2014).

8 Improving engineering in harsh environments

\section{Climate}

Climate significantly influences plant development and function. Some of the world's harshest conditions for plant growth occur in high altitude environments, with sharp fluctuations in temperatures and precipitation (Körner 2003). Areas receiving little precipitation often support reduced vegetation cover and large areas of exposed bare soil, which may increase vulnerability to erosion. Extreme precipitation events during seasonal monsoons can result in high erosive forces and soil saturation, leading to erosion, landslides and earth flows (Sidle and Ochiai 2006). In urban environments, anthropogenic pressure causes a multitude of stressful conditions for plants, including pollution, soil compaction, drought, unsuitable growth medium and lack of plant propagules (Walker and Shiels 2013). Nevertheless, plant species with necessary adaptations, or high plasticity, may tolerate and persist where extreme climate, resource and topographical conditions are frequent. Identifying species with traits which make them suitable for restoration actions is the first challenge towards the successful restoration of a site in harsh environments.

\section{Topography}

The topography of an extreme environment can determine the success of planting and restoration programs. Bochet et al. (2009) investigated topographic thresholds (slope angle and aspect) for plant colonization on semiarid eroded slopes in Spain, and observed that the slope angle threshold for plant colonization decreased from north-facing slopes $\left(63^{\circ}\right)$ to south-facing slopes $\left(41^{\circ}\right)$. Variations in slope angle threshold values between slope aspects resulted from differences in the colonization capacity of plants and was controlled by water availability, which was in turn controlled only by the solar radiation received (and not by soil hydrological properties). Although such studies are site-dependent, they provide a useful methodology to determine topographic thresholds for plant colonization in hilly areas (Hales et al. 2009).

\section{Substrate}

Soils on slopes can be in a disturbed state, due to engineering activities, previous erosion or current erosion processes. Although topographic thresholds are important for colonization, root/soil interactions play a critical role in plant establishment and success. Roots and soil have the ability to engineer and affect each other in complex interactions (Preti and Giadrossich 2009; Loades et al. 2010; Preti et al. 2010). For example, soils with a high bulk density (e.g., compacted soils), will increase root penetration resistance, eliciting a response affecting root system architecture (e.g., by increasing root diameter; Materechera et al. 1992) and the depth to which roots can penetrate (Pietola and Smucker 1998). The response to soil pressure exerted at the root-soil interface will differ between species. Therefore, understanding how and why plant species respond to various 
soil physical properties is a key objective in future research programs.

\section{Keystone and native species}

Mortality can be high for introduced species on hillslopes where climate or substrate conditions are not conducive to plant survival. The use of native keystone species is thus a recommended solution for planting on slopes in such environments. Keystone species are defined as having a disproportionately large effect on the local environment, relative to their abundance (Paine 1995). Caprez et al. (2011) showed that the highly drought resistant, clonal grass species, Festuca valesiaca Schleich., was dominant at the edge of erosion gullies in the Central Caucasus, Georgia. The dry conditions at the edge of erosion gullies likely corresponded to its ecological niche. Similarly, the clonal broadleaf tree species, Alnus viridis Chaix., is dominant in gullies and avalanche tracks in the European Alps. This drought resistant, nitrogen-fixing species possesses flexible stems, permitting it to bend without breaking during avalanches (Stokes et al 2012). Clonal propagation contributes significantly to the robustness of plants subjected to disturbance (Körner 2003). By identifying native clonal species, particularly those which are creeping or grow as thickets, and that are frequently found in harsh environments, it is possible to determine keystone species useful for planting on slopes where climate or substrate conditions are extreme.

\section{Restoration actions}

Effective long-term slope stability and erosion control is achieved through ecosystem recovery, including the reestablishment of community and ecosystem properties such as complexity, self organization and resilience that reduce the need for human maintenance with time. Beyond plants, community components include soil organisms, dispersers, pollinators, and herbivores. Restoration actions in a stressful or extreme environment will depend on specific goals given a particular set of site conditions (Table 1), and range from adding mulch, plants, microbes or fertilizers, to promoting desirable successional stages or transitions (Walker and Shiels 2013). Case studies (Boxes 1, 2), whereby slope stability is restored and erosion arrested, provide us with valuable data (Walker and del Moral 2003). Nevertheless, failed projects also indicate areas where more research is needed. Enabling access to data from successful and failed restoration projects would help fill the knowledge gap met when practitioners work on slopes in a harsh environment.

9 Assessing how vegetation on slopes provides ecosystem services

Ecosystem services are the benefits of ecosystem functioning to the overall environment, including the products and services that humans receive from natural, regulated, or otherwise perturbed ecosystems (Costanza et al. 1997; MEA 2005). Benefits can include supporting, regulating, provisioning and cultural services (Table 2, MEA 2005). The complexity of interactions between the different services and their varying responses to land management are caveats to policies often formulated based on one or several subsets of the services (De Groot et al. 2010). Understanding the implications and sustainability of such policy actions is a major priority.

\section{Water provisioning}

Artificial or natural revegetation of a slope may have several benefits in addition to slope stabilization. Hydrological effects include reduction in sediment and nutrient loads of runoff, enhancement of water quality for downstream users (e.g., drinking, hydropower) and reduced peak flows, thereby providing better flood control (e.g., Postel and Thompson 2005). However, the effectiveness of these improvements often depends on the placement and management of these forests in a landscape, and optimizing these co-benefits will necessitate a holistic assessment and understanding of the biophysical response and social demand for these ecosystem services. For example, forests may reduce surface water flow and groundwater availability compared to pastures or croplands and may offset other benefits (Farley et al. 2005; Kim and Jackson 2012).

\section{Carbon sequestration}

Revegetation of a slope may also have positive benefits for climate mitigation by the sequestration of excess carbon. Vegetated land surfaces hold more carbon in their soil and biomass than do surfaces that are sparsely vegetated or where vegetation is absent (Post and Kwon 2000), and different vegetation types also tend to differ in carbon sequestration potential (Jobbagy and Jackson 
Table 1 Restoration activities often required to achieve long-term slope stability vary depending on site conditions and restoration goals

\begin{tabular}{llll}
\hline Site condition & Goal & Action & References \\
\hline Unstable & Stabilize & Add cover plants, divert run-off, terraform (re-shape slope) & Cronin (1992); Morgan (2007) \\
Barren & Increase carbon & Add mulch, limit grazing & Nakamura (1984); Shiels et al. (2006) \\
Infertile & $\begin{array}{c}\text { Increase } \\
\text { nutrients }\end{array}$ & Add nitrogen fixers, microbes, fertilizer & Miles et al. (1984; Fetcher et al. (1996) \\
Too fertile & $\begin{array}{c}\text { Increase } \\
\text { biodiversity }\end{array}$ & Add straw or sawdust, thin dominant vegetation & $\begin{array}{c}\text { Velázquez and Gómez-Sal (2009); Walker } \\
\text { et al. (2010) }\end{array}$ \\
$\begin{array}{c}\text { Arrested } \\
\text { succession }\end{array}$ & $\begin{array}{c}\text { Promote } \\
\text { succession }\end{array}$ & $\begin{array}{c}\text { Improve dispersal, reduce herbivory, utilize legacies, } \\
\text { promote vegetative spread }\end{array}$ & $\begin{array}{c}\text { Negishi et al. (2006); Velázquez and } \\
\text { Gómez-Sal (2008) }\end{array}$ \\
\hline
\end{tabular}

2000). For example, afforestation may increase overall carbon storage compared to pastures or croplands, with the magnitude and direction of these changes varying with climate, soil, species and time (Eclesia et al. 2012). Biological carbon sequestration has been one of the most widely used policy mechanisms for climate change mitigation, and programs such as REDD (Reducing Emissions from Deforestation and Forest Degradation) and CDM (Clean Development Mechanism) should impact positively on research and practical advances in landslide prevention. These programs also target multiple ecosystem services in many regions (Brown et al. 2008). There is a lack of information on the spatial and temporal distribution of soil carbon on a slope and how it is altered above- and below-ground by monocultures and mixtures of species, and at different ages or successional stages.

\section{Diverse effects}

Natural regeneration on a restored hillslope may increase the diversity of native flora and fauna in the area
(Cavaillé et al. 2013). Higher biodiversity can enhance overall ecosystem functioning such as nutrient cycling and resilience to disturbances such as drought and hurricanes (Loreau et al. 2001). In addition, forests may serve as habitats or migration corridors for certain species that bring economic benefits, such as pollination of crops or wildlife eco-tourism and other recreational activities (Kremen et al. 2007). Trees and large shrubs can create shade for livestock and biomass for firewood and construction. In conjunction with improved fish and wildlife habitat along watercourses, establishment of vegetation improves human habitat and recreational use in urban areas by creating shade and improving aesthetics and air quality. In some countries with dry and historically treeless ecosystems, forests or woodlands are a desirable and actively managed land use (Fisher 2004). Timber harvests can also diversify the local economy and help rural development (Brown et al. 2008). Many other environmental co-benefits and costs of ecological engineering of unstable slopes exist (e.g., remediation of polluted soil; Perez-Esteban et al. 2014,

Table 2 A variety of ecosystem services are provided by vegetation on slopes

\begin{tabular}{|c|c|c|c|}
\hline Supporting & Provisioning & Regulating & Cultural \\
\hline $\begin{array}{l}\text { Slope and embankment } \\
\text { stabilization }\end{array}$ & Fuel and energy production & $\begin{array}{l}\text { Phytostabilization of polluted } \\
\text { sites (e.g., mines) }\end{array}$ & Educational \\
\hline $\begin{array}{l}\text { Soil conservation and } \\
\text { prevention of soil erosion }\end{array}$ & Fodder & Regulation of water quality & Recreational \\
\hline $\begin{array}{l}\text { Primary production } \\
\text { and biodiversity }\end{array}$ & $\begin{array}{c}\text { Food (including fish and game), } \\
\text { crops, wild foods, and spices }\end{array}$ & $\begin{array}{l}\text { Carbon sequestration and } \\
\text { climate regulation }\end{array}$ & Religious ceremonies \\
\hline $\begin{array}{l}\text { Biogeochemical dispersal } \\
\text { and cycling }\end{array}$ & Medicines and herbal remedies & Stormwater control & Ornamental value \\
\hline Habitat creation & Cosmetics and (insect) repellent & Purification of air & Heritage tree value \\
\hline Seed dispersal & $\begin{array}{l}\text { Wood for house construction and } \\
\text { production of agricultural tools } \\
\text { Resin, gum, latex, dye, tannin, } \\
\text { oil and fibre production }\end{array}$ & $\begin{array}{l}\text { Shelter from wind and shade from sun } \\
\text { (for humans, animals, fish and } \\
\text { understory plants) }\end{array}$ & \\
\hline
\end{tabular}


this issue). Therefore, a careful identification of biophysical processes and socially desirable services should accompany the choice of appropriate plant species and their management in any restoration program (Table 2, Reubens et al. 2011).

10 Improving the widespread adoption of ecoand bio-engineering

\section{Hesitations in the engineering community}

Civil and geotechnical engineers have several concerns about using soft engineering techniques. First, soil bioengineering is often viewed as simply the stabilisation of superficial layers, with effectiveness limited to the depth permeated with roots. Although this is correct with regard to the effects of live vegetation only, reinforcing effects deeper in the soil are possible through the addition of inert but natural materials (Gray and Sotir 1996). Another perceived shortcoming is the low durability of the system/strategy, yet we argue that the durability over time is comparable to that of civil engineering structures (Fig. 5; Böll et al. 2009). The natural variability that occurs in soft engineering structures is thought to hinder the quantification or assessment of the installation. This factor, however, is not detrimental to the effectiveness of the structure (if it is not caused through rapid pathogen attack), and civil/geotechnical engineers need to be aware of such variability and take it into account in assessments. In situations where immediate stabilization is required, such as roadsides, a suitable approach for engineers would be to use a combination of soft and hard engineering designs to achieve short and long term sustainability as well as deep seated and shallow stability (Gray and Sotir 1996). Such options need to be made rapidly available to stakeholders and the engineering community, with information on the benefits (or not) of soil bio- and eco-engineering rendered accessible in a comprehensive and constructive manner.

\section{Cost analysis}

Another concern about the implementation of soil bioand eco-engineering is its cost. An appropriate approach for cost analysis would be to employ whole life cycle costing (WLCC). WLCC is the systematic consideration of all relevant costs and revenues associated with the acquisition and ownership of an asset, i.e., the stabilised slope (Boussabaine and Kirkham 2004). Costs to be taken into account include both initial capital or procurement costs, opportunity costs and future costs. Only options which meet the performance requirements for the stabilised slope should be considered - those with lower costs over the period will be preferred. This approach would put ecological engineering up for consideration at the earliest possible stage and at the same level as hard engineering solutions. Indirect potential benefits such as the long-term carbon footprint offset should also be emphasized whenever WLCC is carried out (Spaulding et al. 2008), but need better defining and quantifying in the coming years.

\section{Benefits}

Civil engineering structures such as dams, walls, retention basins and other engineered solutions such as terraforming and drainage manipulation are very useful tools for soil loss and erosion control but they have numerous drawbacks. These approaches have a large carbon footprint, are expensive and sometimes dangerous to construct, disrupt local and regional ecological processes, need some ongoing maintenance and eventually need repair or replacement. Ecological approaches, in contrast, have a smaller footprint (Spaulding et al. 2008), promote ecological processes (Walker and Shiels 2013) and a broader range of ecosystem services. Furthermore, ecological approaches are more resilient to ongoing disturbances such as extreme rainstorms and earthquakes. Much still needs to be learned about how an ecological approach responds to abiotic and biotic perturbations, integrates with physical structures, and addresses the needs of local cultures and ecosystems (Fig. 2), yet even partial adoption of ecological tools in conjunction with traditional engineering approaches can have immediate benefits that engineers need to be aware of.

\section{Awareness}

Confidence in soft engineering structures and vegetation cover would increase if awareness was at a high level, and funding agencies or clients asked for and favoured such solutions. For example, in Hong Kong, where steep slopes and monsoon rains have caused thousands of landslides around infrastructure (Choi and Cheung 2013), geotechnical engineers work with landscape architects and botanists to produce mechanically safe, vegetated slopes. Over 60000 man-made slopes are 
referenced in a database open to the public (http://hkss. cedd.gov.hk). Professionals and students are encouraged to access and update the database, and the public desire for 'green slopes' ensures that vegetation is planted, monitored and maintained. Nevertheless, in most of the world, there is a major lack of public awareness and few education and training programs for soil bioand eco-engineers (Stokes et al. 2013). To overcome this problem, the ecological engineering solutions for slope stability could be included in current ecology and engineering modules. Bioengineering qualifications as part of a Continuous Professional Development need to be encouraged, along with practical hands-on experience with established bioengineers. Improving communication and awareness about the benefits of soft engineering options and the use of vegetation to stabilize slopes and fight erosion, is probably the foremost issue for researchers and practitioners to tackle over the next decade.

\section{Ways to improve the working connection between researchers and practitioners}

It is necessary for researchers and practitioners to work together to gain an understanding of what the other is trying to achieve. Research findings should be interpreted in a way that the practitioner can understand and apply, but the practitioner will often have a wider understanding of the problems through both their practical experiences and through their dealings with local authorities. Practitioners provide opportunities for researchers to access work sites, make pertinent observations, and collect useful data. Researchers then gain insights that may not be evident in smaller scale research projects, and the practitioner is likely to involve the researcher in the planning process. The researcher can add value to projects through a better understanding of ecological processes and time scales. Finally, the rate of technology transfer is likely to increase because both researcher and practitioner are involved in the process.

Collaboration between researchers and practitioners could be achieved, ideally, through large-scale, longterm research projects including: i) a field-scale test slope whereby the performance of different treatments, soil and vegetation types is monitored during induced failure and consequential repair; ii) irrigated slopes for infiltration and runoff experiments in treatments with different types of drainage; iii) instrumented slopes for hydrogeological responses to different vegetation types over a number of seasons, which would monitor changes in moisture content, pore water pressures, soil stress state, soil characteristics and sediment transfer; iv) field sites instrumented or monitored with high speed Lidar surveying equipment and video for real-time failure progress or live wireless remote monitoring of displacements/rotations coupled with measurement in soil water pressure. Through such projects, databases could be created, providing input data needed by modelers. Using robust models and data, different vegetation scenarios could be tested.

Although collaborative projects are a priority, forums are required for researchers and practitioners to share results, problems and queries. The international and national networks, such as INBE (International Network of Soil Bio- and Eco-Engineers), EFIB (European Federation for Soil Bioengineering) and AGéBio (French association of soil bioengineering), promote the use of soil bio- and eco-engineering techniques. The aim of these networks is to regroup researchers and practitioners; to create a platform for the exchange of knowledge and information, to learn the questions asked by practitioners and to disseminate data and results.

\section{Conclusions}

Plant species for slope stabilization need to be screened for their ability to establish and grow in the target environment, defined in terms of its specific physical, chemical, ecological and biological characteristics. Identification of species on the basis of suitability for the environment should be followed by screening for plant traits of particular relevance to stabilizing slopes or combating erosion using specified frameworks. Mixtures of species should be encouraged because slope sustainability in most cases can only be obtained through the establishment of successional processes that can reduce intervention and be a long-term solution for restoration and protection. While restoration of native ecosystems and provision of a broad spectrum of ecosystem services may be desirable in some situations, in others, local land use on slopes relies on the longevity of one or two species for slope stability, rather than natural vegetation succession. The link between slope hydrology and vegetation types needs significantly more research, along with the influence of vegetation and soil fauna on soil formation, physical, chemical and 
ecological processes. A better understanding is required of the services provided by vegetation on slopes, other than its stabilizing features. More precise modelling studies over space and time will provide useful tools for the civil and geotechnical engineering communities, who are still wary about using soft engineering structures and associated vegetation. Awareness of soil bioand eco-engineering techniques needs to increase significantly, through collaborative projects, communication, training and education.

Acknowledgments Funding was provided by the French project 'Ecosfix. Ecosystem Services of Roots - Hydraulic Redistribution, Carbon Sequestration and Soil Fixation,' ANR-2010-STRA-00301 (TF, JHK, ZM, AS) and the BMU (Germany) International Climate Initiative funded project 'Ecosystems Protecting Infrastructure and Communities' (EPIC, coordinated by IUCN and ProAct, Switzerland), (JHK, AS). Thanks are due to the University of British Columbia, Canada, for hosting the Third International Conference on Soil Bio- and Eco-Engineering - The Use of Vegetation to Improve Slope Stability, 23-27 July 2012. We are grateful to P. Hinsinger (INRA, Section Editor at Plant and Soil) and three anonymous reviewers for their comments.

\section{References}

Ammann M, Böll A, Rickli C, Speck T, Holdenrieder O (2009) Significance of tree root decomposition for shallow landslides. For Snow Landsc Res 82(79-94):79

Atkins RJ, Leslie MR, Polster DF, Wise MP, Wong RH (2001) Best management practices handbook: Hillslope Restoration in British Columbia. Watershed Restoration Technical Circular No. 3 (Revised). B.C. Ministry of Forests. Victoria, B.C., Canada

Ayininuola GM, Agbede OA, Franklin SO (2009) Influence of calcium sulphate on subsoil cohesion and angle of friction. $\mathrm{J}$ Appl Sci Res 5:297-304

Bais HP, Weir TL, Perry LG, Gilroy S, Vivanco JM (2006) The role of root exudates in rhizosphere interations with plants and other organisms. Annu Rev Plant Biol 57:233-266

Barker DH, Watson AJ, Sombatpanit S, Northcutt B, Magliano AR (eds) (2004) Ground and water bioengineering for erosion control and slope stabilization. Science Publishers, Inc., $\mathrm{NH}, 419 \mathrm{p}$

Barré P, Hallett PD (2009) Rheological stabilization of wet soils by model root and fungal exudates depends on clay mineralogy. Eur J Soil Sci 60:525-538

Bischetti GB, Vergani C, Chiaradia EA, Bassanelli C (2014) Root strength and density decay after felling in a Silver FirNorway Spruce stand in the Italian Alps. Plant Soil, this issue

Boardman J, Poesen J (2006) Soil erosion in Europe. Wiley, Chichester, p 855

Bochet E, Garcia-Fayos P, Poesen J (2009) Topographic thresholds for plant colonization on semi-arid eroded slopes. Earth Surf Process Landf 34:1758-1771
Böll A, Burri K, Gerber W, Graf F (2009) Long-term studies of joint technical and biological measures. For Snow Landsc Res 82(9-32):9

Bonneu A, Dumont Y, Rey H, Jourdan C, Fourcaud T (2012) A minimal continuous model for simulating root growth and development of plant root systems. Plant Soil 354:211-227

Bourrier F, Kneib F, Chareyre B, Fourcaud T (2013) Discrete modelling of soil reinforcement by plant roots. Ecol Eng 61P:646-657

Boussabaine A, Kirkham R (2004) Whole life-cycle costing: Risk and risk responses. Wiley, Chichester, p 268

Briggs KM, Smethurst JA, Powrie W, O'Brien AS, Butcher DJE (2013) Managing the extent of tree removal from railway earthwork slopes. Ecol Eng 61P:690-696

Brown D, Seymour F, Peskett L (2008) How do we achieve REDD co-benefits and avoid doing harm? In: Angelsen A (ed) Moving ahead with REDD. CIFOR, Bogor, pp 107-118

Bryan RB (2000) Soil erodibility and processes of water erosion on hillslope. Geomorphology 32:385-415

Caprez R, Spehn E, Nakhutsrishvili G, Körner C (2011) Drought at erosion edges selects for a 'hidden' keystone species. Plant Ecol Divers 4:303-311

Capriel P, Beck T, Borchert H, Härter P (1990) Relationships between soil aliphatic fraction extracted with supercritical hexane, soil microbial biomass, and soil aggregate stability. Soil Sci Soc Am J 54:415-420

Cavaillé P, Dommanget F, Daumergue N, Loucougaray G, Spiegelberger T, Tabacchi E, Evette A (2013) Biodiversity assessment following a naturality gradient of riverbank protection structures in French prealps rivers. Ecol Eng 53:23-30

Choi KY, Cheung RWM (2013) Landslide disaster prevention and mitigation through works in Hong Kong. J Rock Mech Geotech Eng 5:354-365

Corcoran MK, Peters JF, Dunbar JB, Llopis JL, Tracy FT, Wibowo JL, Simms JE, Kees CE, McKay SK, Fischenich JC, Farthing MW, Glynn ME, Robbins BA, Strange RC, Schultz MT, Clarke JU, Berry TE, Little CD, Lee LT (2011) Initial research into the effects of woody vegetation on levees. Volume IV. US Army Corps of Engineers, Engineer Research and Development Center, Washington DC

Costanza R, D'Arge R, Farber S, Grasso M, Hannon B, Limburg K, Naeem S, O’Neill R, Paruello J, Raskin RG, Sutton P, Van den Belt M (1997) The value of the world's ecosystem services and natural capital. Nature 387:253-260

Craig RF (2004) Craig's soil mechanics, 7th edn. Spon Press, London, p464

Cronin VS (1992) Compound landslides: nature and hazard potential of secondary landslides within host landslides. Rev Eng Geol 9:1-9

Czarnes S, Hallett PD, Bengough AG, Young IM (2000) Rootand microbial-derived mucilages affect soil structure and water transport. Eur J Soil Sci 51:435-443

De Baets S, Poesen J, Reubens B, Muys B, De Baerdemaeker J, Meersmans J (2009) Methodological framework to select plant species for controlling rill and gully erosion: application to a Mediterranean ecosystem. Earth Surf Process Landf 34: 1374-1392

De Groot RS, Alkemade R, Braat L, Hein L, Willemen L (2010) Challenges in integrating the concept of ecosystem services and values in landscape planning, management and decision making. Ecol Complex 7:260-272 
Donzé FV, Richefeu V, Magnier SA (2009) Advances in discrete element method applied to soil, rock and concrete mechanics. In: State of the art of geotechnical engineering. Elect $\mathrm{J}$ Geotech Eng, p.44

Douglas GB, McIvor IR, Potter JF, Foote LG (2010) Root distribution of poplar at varying densities on pastoral hill country. Plant Soil 333:147-161

Duchicela J, Vogelsang KM, Schultz PA, Kaonongbua W, Middleton EL, Bever JD (2012) Non-native plants and soil microbes: potential contributors to the consistent reduction in soil aggregate stability caused by the disturbance of North American grasslands. New Phytol 196:212-222

Eclesia RP, Jobbagy EG, Jackson RB, Biganzoli F, Piñeiro G (2012) Shifts in soil organic carbon for plantation and pasture establishment in native forests and grasslands of South America. Glob Chang Biol 18:3237-3251

EFIB (Europäische Föderation Für Ingenieurbiologie) (1999) Efficacia e costi degli interventi di ingegneria naturalistica. Trieste EFIB-AIPIN, Italy, p 216

Erktan A, Rey F (2013) Linking sediment trapping efficiency with morphological traits of Salix tillers barriers on marly gully floors under ecological rehabilitation. Ecol Eng $51: 212-220$

Evette A, Balique C, Lavaine C, Rey F, Prunier P (2012) Using ecological and biogeographical features to produce a typology of the plant species used in bioengineering for riverbank protection in Europe. River Res Appl 28:1830-1842

Fan CC, Lai Y-F (2014) Influence of the spatial layout of vegetation on the stability of slopes. Plant Soil, this issue

Farley KA, Jobbágy EG, Jackson RB (2005) Effects of afforestation on water yield: a global synthesis with implications for policy. Glob Chang Biol 11:1565-1576

Fattet M, Fu Y, Ghestem M, Ma W, Foulonneau M, Nespoulous J, Le Bissonnais Y, Stokes A (2011) Effects of vegetation type on soil resistance to erosion: relationship between aggregate stability and shear strength. Catena 87:60-69

Fetcher N, Haines BL, Cordero RA, Lodge DJ, Walker LR, Fernández DS, Lawrence WT (1996) Responses of tropical plants to nutrients and light on a landslide in Puerto Rico. J Ecol 84:331-341

Fisher M (2004) Household welfare and forest dependence in Southern Malawi. Environ Dev Econ 9:135-154

Forzieri G, Guarnieri L, Vivoni ER, Castelli F, Preti F (2009) Multiple attribute decision making for individual tree detection using high-resolution laser scanning. For Ecol Manag 258:2501-2510

Fredlund DG (1979) Second Canadian Geotechnical Colloquium: appropriate concepts and technology for unsaturated soils. Can Geotech J 16:121-139

Fredlund DG, Rahardjo H, Fredlund MD (2012) Unsaturated soil mechanics in engineering practice. Wiley, Hoboken

Frei M, Böll A, Graf F, Heinimann HR, Springman S (2003) Quantification of the influence of vegetation on soil stability. Proceedings of the International Conference on Slope Engineering: 8-10 December 2003, Hong Kong, China. pp 872-877

Gecy JL, Wilson MV (1990) Initial establishment of riparian vegetation after disturbance by debris flows in Oregon. Am Midl Nat 123:282-291

Genet M, Kokutse N, Stokes A, Fourcaud T, Cai XH, Ji JN, Mickovski S (2008) Root reinforcement in plantations of
Cryptomeria japonica D. Don: effect of tree age and stand structure on slope stability. For Ecol Manag 256:1517-1526

Genet M, Stokes A, Fourcaud T, Norris JE (2010) The influence of plant diversity on slope stability in a moist evergreen deciduous forest. Ecol Eng 36:265-275

Ghestem M, Sidle RC, Stokes A (2011) The influence of plant root systems on subsurface flow: implications for slope stability. Bioscience 61:869-879

Ghestem M, Veylon G, Bernard A, Vanel Q, Stokes A (2014) Influence of plant root system morphology and architectural traits on soil shear resistance. Plant Soil. doi:10.1007/s11104012-1572-1

Giadrossich F, Schwarz M, Cohen D, Preti F, Or D (2012) Mechanical interactions between neighbouring roots during pullout tests. Plant Soil 367:391-406

Gray DH, Sotir RB (1996) Biotechnical and soil bioengineering slope stabilization: A practical guide for erosion control. Wiley, USA

Gyssels G, Poesen J, Bochet E, Li Y (2005) Impact of plant roots on the resistance of soils to erosion by water: a review. Prog Phys Geogr 29:189-217

Hales TC, Ford CR, Hwang T, Vose JM, Band LE (2009) Topographic and ecologic controls on root reinforcement. J Geophys Res 114:F03013. doi:10.1029/2008JF001168

Hellin J, Haigh MJ (2002) Better land husbandry in Honduras: towards the new paradigm in conserving soil, water and productivity. Land Deg Dev 13:233-250

Jakob M, Hungr O (2005) Debris-flow hazards and related phenomena. Springer, Germany, p739

Jastrow JD, Miller RM, Lussenhop J (1998) Contributions of interacting biological mechanisms to soil aggregate stabilization in restored prairie. Soil Biol Biochem 30:905-916

Ji J, Kokutse NK, Genet M, Fourcaud T, Zhang ZQ (2012) Effect of spatial variation of tree root characteristics on slope stability. A case study on Black Locust (Robinia pseudoacacia) and Arborvitae (Platycladus orientalis) stands on the Loess Plateau, China. Catena 92:139-154

Jones TA (2013) Ecologically appropriate plant materials for restoration applications. Bioscience 63:211-219

Kim JH, Jackson RB (2012) A global analysis of groundwater recharge for vegetation, climate, and soils. Vadose Zone J. doi:10.2136/vzj2011.0021RA

Körner C (2003) Alpine plant life - functional plant ecology of high mountain ecosystem, 2nd edn. Springer, Heidelberg

Kremen C, Williams NM, Aizen MA, Gemmill-Herren B, LeBuhn G, Minckley R, Ricketts TH (2007) Pollination and other ecosystem services produced by mobile organisms: a conceptual framework for the effects of land-use change. Ecol Lett 10:299-314

Kuzovkina YA, Volk TA (2009) The characterization of willow (Salix L.) varieties for use in ecological engineering applications: co-ordination of structure, function and autecology. Ecol Eng 35:1178-1189

Lacasse and Vanier (1999) Durability of building materials and components 8: Durability of building assemblies and methods of service life prediction. Volume 1: Service Life and Durability of Materials and Components. NRC Research Press, Ottawa, p 898

Lancaster ST, Hayes SK, Grant GE (1999) The interaction between trees and the landscape through debris flows. EOS Trans Am Geophys Union 80(46):F425 
Le Bissonnais Y (1996) Aggregate stability and assessment of soil crustability and erodibility: I. Theory and methodology. Eur J Soil Sci 47:425-437

Loades KW, Bengough AG, Bransby MF, Hallett PD (2010) Planting density influence on fibrous root reinforcement of soils. Ecol Eng 36:276-284

Loreau M, Naeem S, Inchausti P, Bengtsson J, Grime JP, Hector A, Wardle DA (2001) Biodiversity and ecosystem functioning: current knowledge and future challenges. Science 294:804-808

Mao Z, Jourdan C, Bonis ML, Pailler F, Rey H, Saint-André L, Stokes A (2013) Modelling root demography in heterogeneous mountain forests and applications for slope stability analysis. Plant Soil 363:357-382

Mao Z, Bourrier F, Stokes A, Fourcaud T (2014) Threedimensional modelling of slope stability in heterogeneous montane forest ecosystems. Ecol Model 273:11-22

Materechera SA, Alston AM, Kirby JM, Dexter AR (1992) Influence of root diameter on the penetration of seminal roots into a compacted subsoil. Plant Soil 144:297-303

McIvor IR, Douglas GB, Benavides R (2009) Coarse root growth of Veronese poplar trees varies with position on an erodible slope in New Zealand. Agrofor Syst 76:251-264

McIvor I, Sloan S, Pigem LR (2014) Genetic and environmental influences on root development in cuttings of selected Salix and Populus clones - a greenhouse experiment. Plant Soil, this issue

Mickovski SB, van Beek LPH (2009) Root morphology and effects on soil reinforcement and slope stability of young vetiver (Vetiveria zizanioides) plants grown in semi-arid climate. Plant Soil 324:43-56

Mickovski SB, van Beek LPH, Salin F (2005) Uprooting resistance of vetiver grass. Plant Soil 278:33-41

Mickovski SB, Stokes A, van Beek LPH, Ghestem M, Fourcaud T (2011) Simulation of direct shear tests on rooted and nonrooted soil using Finite Element analysis. Ecol Eng 37:15231532

Miles DWR, Swanson FJ, Youngberg CT (1984) Effect of landslide erosion on subsequent Douglas-fir growth and stocking levels in the Western Cascades, Oregon. Soil Sci Soc Am J 48:667-671

Millennium Ecosystem Assessment (MEA) (2005) Ecosystems and human well-being: Synthesis. Island Press, Washington, p 155

Mitchell SJ (2013) Wind as a natural disturbance agent in forests: a synthesis. Forestry 86:147-157

Mitsch WJ, Jørgensen SE (2004) Ecological engineering and ecosystem restoration. Wiley, New York

Morgan RPC (2007) Vegetative-based technologies for erosion control. In: Stokes A, Spanos I, Norris JE (eds) Eco- and ground bio-engineering: The use of vegetation to improve slope stability. Springer, Dordrecht, pp 265-272

Nakamura S (1984) Soil survey of american samoa. USDA soil conservation service. U.S. Government Printing Office. 1984 O-412-446 QL 3

National Research Council (1993) Vetiver grass: A thin green line against erosion. National Academy Press, Washington, D.C, 978-0-309-04269-7

Negishi JN, Sidle RC, Noguchi S, Nik AR, Stanforth R (2006) Ecological roles of roadside fern (Dicranopteris curranii) on logging road recovery in Peninsular Malaysia: Preliminary results. For Ecol Manag 224:176-186
Normaniza O, Barakbah SS (2011) The effect of natural succession on slope stability. Ecol Eng 37:139-147

Norris JE, Stokes A, Mickovski SB, Cammeraat E, van Beek R, Nicoll BC, Achim A (eds) (2008) Slope stability and erosion control: Ecotechnological solutions. Springer, The Netherlands

Onate E, Idelsohn SR, Del Pin F, Aubry R (2004) The particle finite element method, an overview. Int J Comput Meth 1: 267-307

Paine RT (1995) A conversation on refining the concept of keystone species. Conserv Biol 9:962-964

Peng X, Hallett PD, Zhang B, Horn R (2011) Physical response of rigid and non-rigid soils to analogues of biological exudates. Eur J Soil Sci 62:676-684

Perez-Esteban J, Escolástico, Moliner A, Masaquer A, RuizFernández J (2014) Phytostabilization of metals in mine soils using Brassica juncea in combination with organic amendments. Plant Soil, this issue

Petley D (2012) Global patterns of loss of life from landslides. Geology 40:927-930

Petrone A, Preti F (2010) Soil bio-engineering for risk mitigation and environmental restoration in a humid tropical area. Hydrol Earth Syst Sci 14:239-250

Pierson TC (1985) Initiation and flow behavior of the 1980 Pine Creek and Muddy River lahars, Mount St. Helens, Washington. Geol Soc Am Bull 96:1056-1069

Pietola L, Smucker AJM (1998) Fibrous carrot root responses to irrigation and compaction of sandy and organic soils. Plant Soil 200:95-105

Poesen J, Nachtergaele J, Verstraeten G, Valentin C (2003) Gully erosion and environmental change: importance and research needs. Catena 50:91-133

Pollen N (2007) Temporal and spatial variability in root reinforcement of streambanks: accounting for soil shear strength and moisture. Catena 69:197-205

Pollen-Bankhead N, Simon A (2010) Hydrologic and hydraulic effects of riparian root networks on streambank stability: is mechanical root-reinforcement the whole story? Geomorphology 116:353-362

Polster DF (2006) Soil bioengineering for riparian restoration. Paper presented at the Canadian Land Reclamation Association 2006 Conference, Ottawa, Ontario, August 20 23, 2006

Post WM, Kwon KC (2000) Soil carbon sequestration and landuse change: processes and potential. Glob Chang Biol 63: $317-327$

Postel S, Thompson BH (2005) Watershed protection: capturing the benefits of nature's water supply services. Nat Res Forum 29:98-108

Preti F (2013) Forest protection and protection forest: tree root degradation over hydrological shallow landslides triggering. Ecol Eng 61P:633-645

Preti F, Giadrossich F (2009) Root reinforcement and slope bioengineering stabilization by Spanish Broom (Spartium junceum L.). Hydrol Earth Syst Sci 13:1713-1726

Preti F, Dani A, Laio F (2010) Root profile assessment by means of hydrological, pedological and above-ground vegetation information for bio-engineering purposes. Ecol Eng 36: 305-316

Radjai F, Dubois F (2011) Discrete-element modeling of granular materials. Wiley, London, 496p 
Reubens B, Moeremans C, Poesen J, Nyssen J, Tewoldeberhan S, Franzel S, Deckers J, Orwa C, Muys B (2011) Tree species selection for land rehabilitation in Ethiopia: from fragmented knowledge to an integrated multi-criteria decision approach. Agrofor Syst 82:303-330

Rey F (2009) A strategy for fine sediment retention with bioengineering works in eroded marly catchments in a mountainous Mediterranean climate (Southern Alps, France). Land Deg Dev 20:210-216

Rey F, Burylo M (2014) Can bioengineering structures made of willow cuttings trap sediment in eroded marly gullies in a mountainous and Mediterranean climate (Southern Alps, France)? Geomorphology 204:564-572

Rey F, Isselin-Nondedeu F, Bédécarrats A (2005) Vegetation dynamics on sediment deposits upstream of bioengineering works in mountainous marly gullies in a Mediterranean climate (Southern Alps, France). Plant Soil 278:149-158

Rickenmann D (1999) Empirical relationships for debris flows. Nat Hazards 19:47-77

Rinn F, Schweingruber FH, Schär E (1996) RESISTOGRAPH and X-ray density charts of wood. Comparative evaluation of drill resistance profiles and X-ray density charts of different wood species. Holzforsch 50:303-311

Schwarz M, Thormann JJ (2012) Neue Ansätze zur Quantifizierung der Schutzwaldwirkung. Geosciences 2:26-29

Schwarz M, Cohen D, Or D (2012) Spatial characterization of root reinforcement at stand scale: theory and case study. Geomorphology 171-172:190-200

Schwarz M, Giadrossich F, Cohen D (2013) Modeling root reinforcement using a root-failure Weibull survival function. Hydrol Earth Syst Sci 17:4367-4377

Shiels AB, Walker LR, Thompson DB (2006) Organic matter inputs create variable resource patches on Puerto Rican landslides. Plant Ecol 184:223-236

Sidle RC, Ochiai H (2006) Landslides: Processes, prediction, and land use. Water Resources Monogr 18. American Geophysical Union, Washington, D.C

Sidle RC, Ziegler AD, Negishi JN, Nik AR, Siew R, Turkelboom F (2006) Erosion processes in steep terrain - Truths, myths, and uncertainties related to forest management in Southeast Asia. For Ecol Manag. doi:10.1016/j.foreco.2005.12.019

Spaulding CPE, Masse F, LaBrozzi J (2008) Ground improvement technologies for a sustainable world. Civil Eng April: 54-59

Stokes A, Atger C, Bengough AG, Fourcaud T, Sidle RC (2009) Desirable plant root traits for protecting natural and engineered slopes against landslides. Plant Soil 324:1-30
Stokes A, Sotir RB, Chen W, Ghestem M (2010) Soil bio- and ecoengineering in China, past experience and present priorities. Ecol Eng 36:247-257

Stokes A, Mine FX, Mao Z, Brancheriau L (2012) Multistemming and mechanical traits ensure persistence of subalpine woody plants exposed to a disturbance gradient. J Veg Sci 23:325-338

Stokes A, Raymond P, Polster D, Mitchell SJ (2013) Engineering the ecological mitigation of hillslope stability research into the scientific literature. Ecol Eng 61P:615-620

Toll DG, Lourenço SDN, Mendes J, Gallipoli D, Evans FD, Augarde CE, Cui YJ, Tang AM, Rojas JC, Pagano L, Mancuso C, Zingariello C, Tarantino A (2011) Soil suction monitoring for landslides and slopes. Q J Eng Geol Hydrogeol 44:23-33

Velázquez E, Gómez-Sal A (2008) Landslide early succession in a neotropical dry forest. Plant Ecol 199:295-308

Velázquez E, Gómez-Sal A (2009) Different growth strategies in the tropical pioneer tree Trema micrantha during succession on a large landslide on Casita Volcano, Nicaragua. J Trop Ecol 25:249-260

Vrijling JK (2001) Probabilistic design of water defence systems in the Netherlands. Reliab Eng Syst Saf 74:337-344

Walker LR, del Moral R (2003) Primary succession and ecosystem rehabilitation. Cambridge University Press, Cambridge

Walker LR, Shiels AB (2013) Landslide ecology. Cambridge University Press, Cambridge

Walker LR, Landau FH, Velázquez E, Shiels AB, Sparrow A (2010) Early successional woody plants facilitate and ferns inhibit forest development on Puerto Rican landslides. J Ecol 98:625-635

Watson A, Phillips C, Marden M (1999) Root strength, growth, and rates of decay: root reinforcement changes of two tree species and their contribution to slope stability. Plant Soil 217:39-47

Wilkinson AG (1999) Poplars and willows for soil erosion control in New Zealand. Biomass Bioenergy 16:263-274

Wright SF, Green VS, Cavigelli MA (2007) Glomalin in aggregate size classes from three different farming systems. Soil Tillage Res 94:546-549

Zanetti C (2010) Caractérisation du développement des systèmes racinaires ligneux dans les digues. $\mathrm{PhD}$ Thesis, Université de Provence, Aix-Marseille 1, France

Zuazo VHD, Pleguezuelo CRR (2008) Soil-erosion and runoff prevention by plant covers. A review. Agron Sustain Dev 28: 65-86 